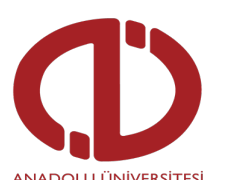

Açıköğretim Uygulamaları ve Araştırmaları Dergisi AUAd

https://dergipark.org.tr/tr/pub/auad

Gönderim: 31.05 .2021

Düzeltme: 09.07.2021

Kabul: 27.07.2021

Tür: Araştırma Makalesi

\title{
Öğrenenlerin acil uzaktan öğretim uygulamasına ilişkin görüş ve önerilerinin ekolojik sistem teorisi bağlamında değerlendirilmesi
}

\section{İrem ERDEM AYDIN ${ }^{a}$}

\author{
a Anadolu Üniversitesi, Açıköğretim Fakültesi. ORCID: 0000-0003-3618-4123
}

\begin{abstract}
Özet
Koronavirüs (COVID-19) küresel salgınından en çok etkilenen alanlardan biri de eğitimdir. Küresel salgın dönemi ile birlikte yürütülemeyen eğitim etkinliklerinin geçici olarak çevrimiçi ortama taşınarak acil uzaktan öğretim (AUÖ) uygulanmaya başlanmıştır. Bu çalışmanın amacı, lisans ve lisansüstü öğrenenlerin küresel salgın sürecinde yürütülen AUÖ uygulamalarına yönelik düşündüklerini belirlemek, kavramsal bir çerçeve içerisinde tartışmaktır. Bu çalışma, durum çalışması olarak desenlemiş, ve çevrimiçi bir anket ile veri toplanıştır. Ankette, üç açık uçlu sorunun yanı sıra öğrenenlerin bazı özellikleri sorgulanmıştır. İlk soruda eğitimlerine devam ettikleri uzaktan eğitim deneyimlerinin geliştirilmesi gereken yönlerini belirlemeleri, ikinci soruda, bu deneyimlerine ilişkin beğendikleri ve olumlu buldukları tarafların neler olduğunu ifade etmeleri istenmiştir. Üçüncü soruda, gelecekte uzaktan eğitimle eğitim almayı isteyip istemediklerini nedenleriyle açıklamaları istenmiş ve bu cevaplar Ekolojik Sistem Teorisi (EST) bağlamında tartışılmaya çalışılmıştır. Çalışma sonunda, AUÖ uygulamalarının altyapı, erişim, tasarım, içerik, mevzuat ve pedagojik açıdan gözden geçirilmesinin gerektiği belirlenmiştir. Öğrenenlerin görüş ve önerilerinin sürecin öğretim tasarımı üzerinde yoğunlaştığı da dikkati çekmiştir
\end{abstract}

Anahtar Sözcükler: Acil Uzaktan Öğretim (AUÖ), Ekolojik Sistem Teorisi, Öğrenci Görüşleri

\section{Examining the learners' perspectives and recommendations regarding emergency remote teaching through the ecological system theory}

\begin{abstract}
Education was one of the most affected areas during the Coronavirus (COVID-19) Pandemic. Because of unrealizability of faceto-face teaching-learning activities in all levels of educational systems, they have temporarily transferred to online environments and offered as Emergency Remote Teaching (ERT). This study intended to explore and discuss the undergraduate and graduate learners' perspectives regarding the ERT implementations through the Ecological System Theory. The study was designed as a qualitative case study and the data collected via an online questionnaire that included three open-ended questions and some others concerning the participants' characteristics. The first open ended question asked the learners indicate the areas to be improved while the second was about the dimensions of ERT they enjoyed and found useful. The last one examined the learners' tendency to take some or all their courses online in the future and the rationales behind their tendencies. The findings were discussed in the light of the Ecological System Theory (EST). The study has revealed that technological infrastructure, accessibility, design, content, and legislation dimensions of the ERT implementations evaluated should be revised. The learners' perspectives and recommendations mostly focused on the design of the courses and programs.
\end{abstract}

Keywords: Emergency Remote Teaching (ERT), Ecological System Theory, Learners' Perspectives 


\section{Giriş}

Küresel salgın tüm dünyada, sağlık, ekonomi, siyasi alan ve sosyal hayatta büyük bir krize neden olmuştur. Küresel salgının etkisini azaltmak ve yayılımını yavaşlatmak için sosyal mesafe uygulamasına geçilmiş ve bu durum günlük hayatta önemli zorlukları ve değişiklikleri beraberinde getirmiştir. Salgın sürecinin tüm dünyada yaratmış olduğu kriz, sağlık, psikolojik, ekonomik ve sosyal hayatın her alanını etkilemiş, eğitim de bu durumdan büyük bir pay almıştır. Okullarda eğitime ara verilmesi, sürecin başında eğitimcileri, öğrencileri, velileri endişeye düşürmüş, tüm ülkeler için en büyük öncelik, eğitimin kesintiye uğramadan devam etmesini sağlayabilmek olmuştur. Bu süreçte UNESCO (2020), okulların ve öğretmenlerin öğrencilere uzaktan ulaşmak ve eğitim kesintisini sınırlamak için, uzaktan eğitim programları ve açık eğitim uygulamalarının ve platformlarının kullanılmasını tavsiye etmiştir. Türkiye'de de salgın, eğitim kurumlarını her seviyede etkilemiş, ilköğretim okulları ve liseler “EBA/Eğitim Bilişim Ağı” sistemi ile eğitim faaliyetlerini sürdürmüşlerdir. Bu süreçte Millî Eğitim Bakanlığına bağlı bütün okullarda, 23 Mart sonrasında, uzaktan eğitim yöntemiyle internetten ve televizyon kanallarından eğitimlere devam edilmiştir. Yükseköğretim Kurumu'na (YÖK) bağl1 üniversitelerin de Mart 2020'de eğitimlerine ara vermeleri sonucu, eğitim kesintiye uğramıştır. Bu sebeple YÖK (2020) öğrenme sürecinin aksamaması adına düzenlediği mevzuatla, tüm üniversitelerde 23 Mart 2020 tarihinden itibaren uzaktan eğitim uygulamalarına geçmiştir.

Uzaktan eğitim uygulamaları örgün öğretime destek olmak yanında, farklı kriz durumlarında eğitim açığını kapatan önemli bir seçenek olarak karşımıza çıkmıştır. Bugün yaşananlar, açık ve uzaktan eğitim uygulamalarının eğitimin sürdürülebilirliği açısından en kolay ve uygulanabilir çözüm olduğunu göstermektedir. Öte yandan küresel salgın nedeniyle yükseköğretim kurumlarında yürütülen uzaktan eğitim normal sürecinden farklı dinamiklere sahiptir. Yapılmakta olan, yaşanan olumsuz koşullar dolayısıyla yüz yüze yürütülemeyen eğitim etkinliklerinin geçici olarak çevrimiçi ortama taşınmasıdır ve Acil Uzaktan Öğretim olarak (AUÖ) adlandırılmaktadır. Yaşadığımız durumun aciliyeti hızlı hareket etmeyi, çabuk karar almayı gerektirmiştir. Bu bağlamda çevrim içi dersleri etkili bir şekilde yapacak deneyim ve zamana sahip olunmamasının, uzaktan eğitim sürecinin tüm bileşenleriyle işletilmesine engel olduğu görülmektedir. Bu nedenle yaşanan durum, acil sorun karşısında üretilen mevcut ihtiyacı karşılamaya yönelik geçici bir çözüm olarak düşünülmelidir (Chuck vd, 2020; Golden, 2020). AUÖ ifadesinde eğitim yerine “öğretim” kavramının vurgulanması, acil gelişen bu sürecin daha çok öğretmenlerin sorumluluğu altında yürütülmesinden kaynaklanmaktadır 
(Hodges vd, 2020) ve öğretim etkinliklerinin geleneksel sınıf ortamındaki bağlamından koparmadan sürdürülmesi amaçlanmaktadır. AUÖ'de uzun vadeli planlar yapmak ve sistem kurmak yerine, var olan ihtiyacı karşılayacak, öğretim faaliyetlerinin aksamadan yürütülmesini sağlayacak bir basamak oluşturmak hedeflenmektedir. Bu bağlamda AUÖ, farklı kriz durumlarında yaşanabilecek öğretim kaynaklı boşlukların doldurulmasını amaçlayan bir model olarak değerlendirilebilir. Uzaktan eğitim sürecinin öğrenene farklı öğrenme bileşenlerini esneklik içinde sunan bir yapısı vardır. Oysa ki AUÖ bir seçenek değil zorunluluk olarak karşımıza çıkmıştır ve uzun vadeli sürdürülebilir bir öğrenme ekosistemi kurma amacında değildir. Bu nedenle bu sistemin öğrenenlere uzaktan eğitimin sağladığı esnekliği sunmadığ1 ve bu noktada AUÖ modelinin, uzaktan eğitim modelinden farklılaştığı söylenebilir (YÖK, 2020).

Küresel salgın dönemi ile birlikte AUÖ uygulamalarının değerlendirilmesine yönelik çalışmaların artış gösterdiği görülmektedir. Yapılan çalışmalarda (Altun, 2020; Andoh, Appiah ve Agyei, 2020; Bergdahl ve Nouri,2020; Can, 2020; Durak vd., 2020; Edelhauser ve LupuDima, 2020) altyap1 ve teknolojiye erişim sorunlarına değinilmiş, değerlendirme sürecinin zorluğuna vurgu yapılmış, öğrenenlerin motivasyon kaybına ilişkin sorunlar dile getirilmiş. Ön görülemeyen küresel salgın süreci ve yaşanan krizin yaratığg boşluğu hızlıca doldurmak zorunluluğu, bu çalışmaların genel olarak var olan durumu tasvir etmeyi, uygulamalar arasında karşılaştırma yapmayı, gerçekleştirilen uygulamalara ilişkin bilgi vermeyi amaçladığı görülmektedir. $\mathrm{Bu}$ çalışmada ise, öğrenenlerin görüşleri daha sistematik bakış açısıyla değerlendirilmeye çalışılmış, kavramsal çerçeveyi çizebilmek için Ekolojik Sistem Teorisinden (EST) yararlanılmıştır.

\section{Ekolojik Sistem Teorisi}

Bronfenbrenner (1979) tarafından geliştirilen EST, kişi ve kişinin çevresi arasındaki karşılıklı ilişkiye odaklanır ve bireylerin davranışlarını anlayabilmek için, içinde yer aldığı çevreyle ve sistemle ilişkisi bağlamında değerlendirmek gerektiğini ileri sürer. Bu yaklaşım ile sistemin tüm bileşenleri ve aralarındaki etkileşim ortaya koyularak, olayları bütüncül bir bakış açısı ile açıklayabilmek mümkün olmaktadır. Diğer sistem teorilerinden farklı olarak insanın, içinde yer aldığı sayısız çevresel faktörlerle kurduğu etkileşim ve eylemlere odaklamaktadır (Bronfenbrenner, 2004). ETS'de, bazı çevresel sistemlerin bireyin psikolojik gelişimi üzerinde etkili olduğunu belirtmekte, bunların da insanlarla doğrudan etkileşimde bulunduğu en yakın bağlamdan daha geniş kültürel bağlama kadar uzandığını vurgulamaktadır (Bronfenbrenner ve 
Morris, 2006). ETS'ye göre, bireylerin etkileştiği çevresel sistem beş basamaktan oluşmaktadır. Mikrosistem (Microsystem), bireyin en yakın çevresi olan, gelişimini en hızlı ve doğrudan etkileyen grupları ve kurumları ifade eder. Bunlar; aile, okul, dini kurumlar, yakın çevre, komşular ve arkadaşlardır (Paquette ve Ryan, 2001). Mezosistem (Mesosystem), mikrosistemler arasındaki ilişkileri ya da bağlamlar arasındaki ilişkileri ifade eder. Aile yaşantılarının okul yaşantıları ile ilişkisi, okul yaşantılarının dini yaşantıları etkilemesi ve aile yaşantılarının arkadaş yaşantılarını etkilemesi gibi örnekler verilebilir (Berk, 2000; Bronfenbrenner, 1979; Swick ve Williams,2006). Ekzosistem (Exosystem), mezosistemin bir uzantısı oluğu söylenebilir, bireyin aktif rol almadığı sosyal bir kuruluş ile bireyin içinde bulunduğu bağlam arasındaki ilişkiyi ifade eder (Bronfenbrenner,2005). Kronosistem (Kronosystem), zaman içinde değişen sosyo-tarihsel, sosyo-kültürel ve çevresel koşulların bireyin yaşamındaki geçişlere yansıması ve deneyimlerini etkilemesi olarak ele alınmıştır (Greenberg, Domitrovich ve Bumbarger, 2001; Sheridan, Warnes, Cowan, Schemm ve Clarke, 2004).

McCalla'ya (2004) göre EST, eğitimde öğrenciyi etkileyen veya etkileyebilecek değişkenleri içeren bir yaklaşım olması açısından, öğrencinin öğrenme sürecindeki davranışlarının anlaşılmasına yardımcı olabilir. Bu çalışmada da Bronfenbrenner'in ekolojik yaklaşımının, eğitim sistemindeki sorunları ve nedenlerini daha iyi anlamak ve toplum yararına daha etkin çözüm yolları oluşturmak için genel bir çerçeve sunabileceği düşünülmektedir. Eğitim sistemi, öğrenciler, öğretmenler, diğer öğrenciler, veliler gibi birbiriyle iletişim halinde olan bileşenlerden oluşmaktadır ve ekonomi, politika, sosyal normlar, kültür gibi farklı bileşenlerle de etkileşim halindedir. Eğitim sürecinin bir bileşenindeki değişimin diğerlerine olan etkisini de göz önünde bulundurduğundan ETS bakış açısının eğitim ortamlarının dinamiğinin daha iyi anlaşılmasını sağlayabileceği düşünülmektedir.

Johnson ve Cooke'da (2020), çevrimiçi öğrenme ortamlarında öğrenci etkileşimi sürecini EST bağlamında açıklamışlardır (Şekil 1). Ekolojik e-öğrenme modelinde (Champaign ve Cohen, 2011; Johnson, 2008; Johnson, 2014; McCalla, 2004) e-öğrenci, bir dizi iç içe geçmiş, büyük bir sistemin merkezinde yer almakta ve bu sistemin; bioekoloji, arayüz, mikrosistem, ekzosistem, makrosistem ve kronosistem bileşenlerinden oluşmaktadır. Bioekoloji bileşeni eöğrenenin, öğrenme biçimi, teknoloji kullanma deneyimi, tutumları, demografik özellikleri gibi öğrenen özelliklerini kapsamaktadır. Johnson ve Puplampu (2008), arayüz alt sistemini, teknolojinin yönlendirici gücünden yola çıkarak, birey ve mikrosistem arasında çift yönlü iletişime aracılık ettiği düşüncesiyle yeni bir basamak olarak kabul etmişlerdir. Özellikle bugün 
küresel salgın sürecinde teknoloji, öğrenme sürecinin önemli bir parçası olarak rol almış, öğreten, diğer öğrenenler ve bilgiyle etkileşim içinde bulunmasını sağlayan bir unsur olarak karşımıza çıkarmıştır. EST'nin ilk çıktığı dönemde, teknoloji günümüzdeki kadar gelişmiş değildi ve bireyin yaşantısında bu derece yönlendirici bir gücü de yoktu. Johnson ve Cooke'da (2020) geliştirdikleri modelde, mezosistemi kaldırıp, arayüz alt sistemini ekleyerek ekolojik sistemler teorisinin gelişimine katkıda bulunmuşlardır. Dijital devrimin insan-çevre etkileşiminin doğasını değiştirmesi sonucu, arayüz alt sistemi çevrimiçi ortamlarda öğrenenin tüm etkileşim sürecine aracılık eden bir basamak haline gelmiştir. Diğer yandan, Johnson ve Cooke (2020) modeline göre mikrosistemde, bireyin en yakın çevresi olan, gelişimini en hızlı ve doğrudan etkileyen gruplarla etkileşimi gerçekleşmektedir. Bu bağlamda mikrosistem, üç temel etkileşim türü olan, öğrenci-öğrenen, öğrenen-öğreten ve öğrenen-içerik etkileşiminin gerçekleştiği bölümdür. Ekzosistem, öğrenme sürecinin tasarımıyla ilgili etkinliklerin yer aldığı basamaktır. Amaçların belirlenmesi, içeriğin aktarımı, etkinliklerin yapılması, değerlendirme gibi öğretim tasarım sürecine ait bileşenler ekzosistem içerisinde yer almaktadır. Modelde, makrosistem ve kronosistem, çevrimiçi öğrenme ortamlarında öğrenci etkileşimi üzerinde dolaylı da olsa güçlü bir etkiye sahiptir. Makrosistem üniversite kültüründen (örneğin değerler, gelenekler, prosedürler, süreçler ve altyapılar) oluşur. Üniversite değerleri, çevrimiçi öğrenme fırsatlarının oluşmasında ve kalitesinde belirleyici olarak karşımıza çıkmaktadır. Kronosistem, modeldeki son katmandır ve içinde yaşanılan zaman dilimini anlatmaktadır. Hem öğrenenden hem de yaşadığımız ortamdan kaynaklanan değişimlerle şekillenir. Herhangi bir toplumdaki değerler, gelenekler, teknoloji ve sosyal durumlar zaman içerisinde değişim gösterir ve bu değişimler de öğrenenin gelişimini etkiler. 


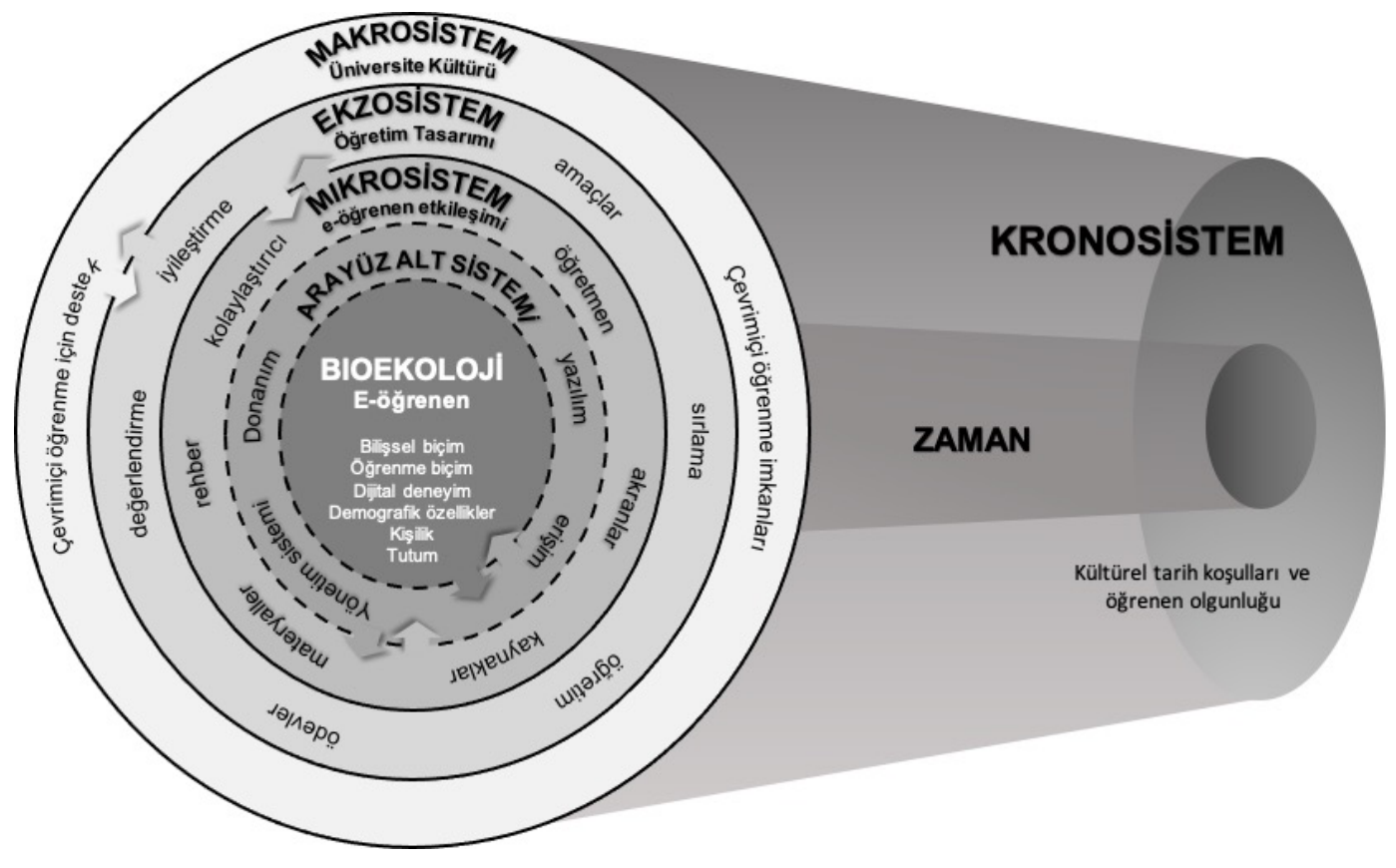

Şekil 1. Çevrimiçi öğrenme ortamlarında öğrenen etkileşiminin ekolojik modeli (Johnson ve Cooke, 2020)

Eğitim sistemindeki sorunlar, öğretmen, aile, okul atmosferi, çevre koşulları, yönetmelikler, mevzuatlar ve içinde yaşanılan kültürün de rol oynadığ karmaşık problemler olarak karşımıza çıkmaktadır. Küresel salgın sürecinin de eğitim sürecini etkileyen bir sorun olduğu ve bu krizin sistemin bütün bileşenlerini de etkilediği açıktır. AUÖ uygulamalarının da yaşadığımız kriz karşısında eğitim sürecini desteklemek bağlamında önemli bir seçenek olarak çıktığı görülmektedir. AUÖ uygulamalarına ilişkin sorunların bilimsel yöntemlerle belirlenmesi, uygulamalar konusunda tecrübe eksikliğini giderilmesine ve olası farklı afet durumlarına hazırlıklı olunmasını sağlayacaktır. Bu amaçla küresel salgın sürecinde sunulan öğrenme ortamlarının daha etkili ve verimli yapılabilmesi için tüm paydaşların AUÖ'e yönelik bakış açılarını öğrenmek için daha fazla çalışma yapılmalı, derinlemesine incelenmeli ve kavramsal açıklamalar geliştirilmelidir. AUÖ uygulamalarını da bu bakış açısıyla değerlendirilmesinin, sürecinin daha verimli yönetilebilmesi, iyi uygulamalara yönelik ilkelerin belirlenmesi, ileriye yönelik iyileştirme çalışmalarının yapılabilmesi ve politikaların belirlenmesi açısından önemli olacağı düşünülmektedir. Bu önem doğrultusunda bu çalışmada, AUÖ’ye ilişkin öğrenenlerin bakış açısı EST çerçevesinde çizilmeye çalışı1mıştır. 
$\mathrm{Bu}$ bağlamda çalışmanın genel amacı, lisans ve lisansüstü öğrenenlerin küresel salgın sürecinde yürütmek zorunda kaldıkları açık ve AUÖ uygulamaları için ne düşündüklerini belirlemek, EST çerçevesinde tartışmaktır. Bu genel amaç çerçevesinde aşağıdaki sorulara yanıt aranmıştır.

1. Öğrenenler devam ettikleri uzaktan eğitim deneyimlerinin hangi yönlerinin geliştirilmesi gerektiğini düşünüyor?

2. Öğrenenlerin devam ettikleri uzaktan eğitim deneyimine ilişkin beğendikleri, olumlu, yararlı buldukları yönleri nelerdir?

3. Öğrenenler gelecekte uzaktan eğitimle eğitim almak ister mi?

\section{Yöntem}

\section{Araştırma Modeli}

$\mathrm{Bu}$ çalışma, nitel araştırma yöntemlerinden olan durum çalışması ile desenlemiştir. Durum çalışması deseni, güncel olgu ve olayları kendi doğal ortamında ve mevcut durumun ayrınt1l1, düzenli ve derinlemesine irdeleyen bir yöntemdir (Cohen vd. 2007; Patton, 1990). Nitel durum çalışmasının en belirgin özelliklerinden biri, bir sistemin, durumun derinliğine araştırılmasıdır (Merriam, 2018; Yıldırım ve Şimşek, 2013). Durum çalışmalarında araştırmacılar, gerçek yaşam ya da bir durum hakkında gözlem; görüşme, doküman ve raporlar aracılığı ile detaylı ve derinlemesine bilgi toplar (Creswell, 2015). Bu çalışmada da dünya genelinde yaşanan küresel salgın döneminin zorunluluk haline getirdiği AUÖ dönemi öğrencilerin bakış açısıyla değerlendirilmiş ve derinlemesine araştırılmaya çalışılmıştır.

\section{Araştırma Alanı ve Katılımcılar}

Uygulama 70 lisans ve lisansüstü öğrenene uygulanmıştır. Katılımcıların demografik bilgileri Tablo 1'de verilmiştir. Tablo incelendiğinde araştırmaya katılanların çoğunun sosyal bilimler alanından ve yüksek lisans öğrencisi olduğu görülmektedir. Sonuçlara göre kamuda tam zamanlı çalışanların çoğunlukta olduğu ve eğitimleri için başka bir ilden geldikleri görülmektedir. Teknolojiye erişim durumları incelendiğinde 57 öğrenenin evden diz üstü bilgisayarla katıldıkları görülmektedir. 


\begin{tabular}{|c|c|c|c|}
\hline \multicolumn{4}{|c|}{$\begin{array}{l}\text { Tablo } 1 \\
\text { Katılımcı Öğrencilerin Özellikleri }\end{array}$} \\
\hline Özellik & & $\mathbf{N}$ & $\%$ \\
\hline Eğitim Düzeyi & $\begin{array}{l}\text { Lisans } \\
\text { Yüksek Lisans } \\
\text { Doktora }\end{array}$ & $\begin{array}{l}22 \\
30 \\
18 \\
\end{array}$ & $\begin{array}{l}31,4 \\
42,9 \\
25,7 \\
\end{array}$ \\
\hline Eğitim Alanı & $\begin{array}{l}\text { Eğitim } \\
\text { Uzaktan Eğitim } \\
\text { Sosyal Bilimler } \\
\text { İletişim }\end{array}$ & $\begin{array}{l}21 \\
9 \\
34 \\
5\end{array}$ & $\begin{array}{l}31 \\
13 \\
49 \\
7\end{array}$ \\
\hline Meslek & $\begin{array}{l}\text { Öğrenci } \\
\text { Öğretmen } \\
\text { Akademisyen } \\
\text { Kamuda tam zamanlı } \\
\text { Özelde tam zamanlı } \\
\text { Özelde yarı zamanlı } \\
\text { Kendi işi }\end{array}$ & $\begin{array}{l}30 \\
4 \\
14 \\
15 \\
4 \\
2 \\
1 \\
\end{array}$ & $\begin{array}{l}43 \\
6 \\
20 \\
21 \\
6 \\
3 \\
1 \\
\end{array}$ \\
\hline Yaşam Yeri & $\begin{array}{l}\text { Başka il } \\
\text { Aynı il } \\
\text { Ailesine dönen } \\
\text { Aynı il - Yüz yüze eğitime katılmak } \\
\text { istemeyen }\end{array}$ & $\begin{array}{l}49 \\
15 \\
3 \\
3\end{array}$ & $\begin{array}{l}70 \\
22 \\
4 \\
4\end{array}$ \\
\hline İnternet Erişimi & $\begin{array}{l}\text { Evden dizüstü } \\
\text { Evden masaüstü } \\
\text { Evden telefon } \\
\text { İşyeri dizüstü } \\
\text { İşyeri masaüstü }\end{array}$ & $\begin{array}{l}57 \\
7 \\
2 \\
2 \\
1 \\
\end{array}$ & $\begin{array}{l}83 \\
10 \\
3 \\
3 \\
1 \\
\end{array}$ \\
\hline
\end{tabular}

\section{Verilerin Toplanması ve Analizi}

Araştırmanın verileri, araştırmacı tarafından geliştirilmiş olan yarı yapılandırılmış anket formu ile toplanmıştır. Sorular oluşturulurken ilgili alanyazın incelenmiş ve alan uzmanlarının görüşlerinden yararlanılmıştır. Anket formu, küresel salgın yüzünden yüz yüze görüşme olanağı olmadığ1 için çevrimiçi anket üzerinden toplanmıştır. Ankette öğrenenlerin demografik bilgileri sorgulanmış ve üç tane açık uçlu soru yöneltilmiştir. Verilerin toplanmasının ardından içerik analizi çalışması yapılmıştır. İçerik analizi, birbirine benzeyen verileri belirli kavramlar ve temalar çerçevesinde bir araya getirmek ve bunları okuyucunun anlayabileceği biçimde düzenleyerek yorumlamaktır (Yıldırım ve Şimşek, 2013). Diğer bir ifade ile, belirli kodlamalarla bir metnin bazı sözcüklerinin daha küçük içerik kategorileri ile 
özetlendiği sistematik bir teknik olarak tanımlanır (Büyüköztürk vd., 2016). İçerik analizinde temel amaç, toplanan verileri açıklayabilecek kavramlara ve ilişkilere ulaşmaktır.

$\mathrm{Bu}$ amaçla öncelikle veriler kavramsallaştırılır, ardından ortaya çıkan kavramlar mantıksal bir biçimde düzenlenerek veriyi açıklayan temalar saptanır. Bu süreçte öncelikle katılımcıların açık uçlu sorulara verdikleri yanıtlar Word sayfası halinde düzenlenerek kaydedilmiştir. Öğrencilerin yanıtlarındaki anlamlı parçalar cümleler halinde seçilerek kodlanmış, tema ve alt temaları oluşturulmuştur. Böylece katılımcıların verdikleri yanıtlardan elde edilen niteliksel veriler sade bir dille özetlenmiş ve her bir alt probleme ilişkin temalar oluşturulmuştur.

Nitel çalışmalarda, görüşme yöntemi kullanılarak toplanan verilerin güvenirliğini sağlamak için alanda bir uzmanın verileri dinlemesi ve dökümleri okuması önemlidir (Patton, 1990). Bu nedenle çalışmanın güvenirliğini sağlamak için, açık ve uzaktan öğrenme konusunda bir uzman daha aynı işlemi gerçekleştirmiştir. Ardından iki araştırmacının yaptığı kodlamalar karşılaştırılmıştır. Karşılaştırma sonunda kodlamalarda anlamsal açıdan bir farklılığın bulunmadığı, kodlamalarda uyum düzeyinin birbirine yakın olduğu görülmüştür.

Araştırmanın geçerliliğini ve güvenirliliğini sağlamak için, çalışmanın her aşaması açık ve şeffaf bir şekilde açıklanmıştır. Bu çerçevede araştırma yöntemi, çalışma grubu, veri toplama araçları, verilerin toplanması, analiz edilmesi ve bulguların nasıl düzenlendiği ayrıntılı bir şekilde açıklanmıştır. Ortaya çıkan temaları desteklemek için araştırma katılımcılarının örnek yanıtları ilgili kategori ve temalar altında doğrudan alıntı şeklinde kullanılmıştır. Ortaya çıkan temaların kodlamasını öncelikle birinci yazar bağımsız olarak yapmış ve devamında aynı işlem kapsam geçerliliği için görüş veren öğretim üyesi tarafından tekrarlanmıştır. Kodlayıcılar arası güvenliliği hesaplamak için Miles ve Huberman (1994) tarafından önerilen Görüş Birliği / (Görüş Ayrılığg + Görüş Birliğii) x 100 formülü kullanılmış ve kodlayıcılar arası güvenirlik \%89 olarak hesaplanmıştır.

Çalışmada, gerek ilgili alanyazın taranmasında, gerek verilerin toplamasında, gerekse elde edilen verilerin yorumlanmasında etik kurallara uyma konusunda hassasiyet gösterilmiştir. $\mathrm{Bu}$ süreçte veriler bilimsel yöntem çerçevesinde toplanmış, bu verilerin değerlendirilmesinde, yorumlanmasında ve kuramsal sonuçların elde edilmesinde aynı şekilde bilimsel yöntemlerin dışına çıkılmamıştır. Veri toplama sürecinde katılımcıların rızası alınmıştır. Analizlerin sonuçları olduğu gibi değiştirilmeden verilmiş, farklı bilimsel yayınlardan yararlanılırken bilimsel atıf kurallarına uygun olarak kaynak gösterilmiştir. 


\section{Bulgular}

Çalışma kapsamında elde edilen bulgular araştırma soruları bağlamında aşağıda açımlanmış ve tablolarla özetlenmeye çalışılmıştır. Ayrıca her bulgu özetlendikten sonra doğrudan alıntılarla yorumlanmıştır.

Tablo 2'de katılımcı öğrencilerin AUÖ uygulamalarında geliştirilmesi gereken yönlere yönelik görüşleri özetlenmiştir. Bu görüşler EST bağlamında ele alındığında, öncelikle cevapların \%5'inin (f=4) bioekoloji başlığında toplandığı görülmektedir. Cevapları incelediğimizde öğrenenler tarafından, sunum becerilerinin $(\mathrm{f}=1)$, bilişim teknolojilerini kullanma becerilerinin ( $\mathrm{f}=1)$ geliştirilmesi, özdisiplin eksikliğinin giderilmesi $(\mathrm{f}=2)$ gerektiği dile getirilmiştir. Öz disiplin konusunda bir öğrenen düşüncesini “ $\ddot{O}_{z}$ disiplin, başarlya ulaşmak için önemli gerekliliklerden biridir, ancak çoğu zaman öz disiplin eksikliği vardır...” şeklinde dile getirmiştir.

Arayüz Alt Sistemi başlığında verilen cevapların \%17'sinin (f=12) toplandığını görülmektedir. $\mathrm{Bu}$ başlıkta öğrenenler teknik sıkıntıların dersleri aksatmasına $(\mathrm{f}=7)$, teknolojiye ulaşamadıklarıma $(\mathrm{f}=5)$ vurgu yapılmıştır. Bu konuda bir öğrenen "Teknolojik imkanlar herkeste eşit değil maalesef. Kendim de yaklaşık iki ay önce alabildim. Günümüzün ekonomik şartları teknolojik bir aygıt almayı çok zorlaştırıyor ve alamayan ögrenciler derslere katılım sağlayamıyor" cümlesiyle kendisini ifade etmiştir.

Çalışma sonuçlarına göre ekzosistem başlı̆̆ı ise, cevapların \%87'sini ( $\mathrm{f}=61$ ) oluşturmaktadır. Verilen cevaplar incelendiğinde, değerlendirme sisteminin sorunlu olması $(\mathrm{f}=7)$, konuların ayrıntılı işlenememesi $(\mathrm{f}=1)$, etkinliklerin daha etkili ve amaçlar bağlamında olması gerektiği ( $\mathrm{f}=4)$, dile getirilmiştir. Bir öğrenen bu konudaki düşüncesini “Ödevler yerine daha çekici etkinliklerin gerekli olduğunu düşünüyorum" şeklinde ifade etmiştir. Bunun yanında öğrenenler ödevlerin çok yoğun olduğunu $(\mathrm{f}=3)$, geribildirimin daha hızlı olması gerektiği ( $\mathrm{f}=10)$, eşzamansız etkileşim güçlendirilmesi gerektiği $(\mathrm{f}=3)$, aidiyet hissinin oluşturulması gerektiği $(\mathrm{f}=4)$, sosyalleşmenin olmaması $(\mathrm{f}=2)$, öğrenenlerin rol ve sorumluluklarının tanımlanması gerektiği $(\mathrm{f}=1)$, ders süreci önceden yapılandırılması ve öğrenenlerle paylaşılmasının önemli olduğu (f=9), öğrenene danışılmasının gerektiği (f=3), ders kayıtlarının hızla paylaşılmasının önemi ( $\mathrm{f}=2)$, içeriğin uzaktan eğitime uyumlu olmasının gerektiği ( $\mathrm{f}=5)$, tartışma forumlarını öğretenlerin de kullanmaları $(\mathrm{f}=1)$, örgün eğitimdeki 
içeriğin olduğu gibi aktarılmamasının $(\mathrm{f}=6)$ gerektiği dile getirilmiştir.

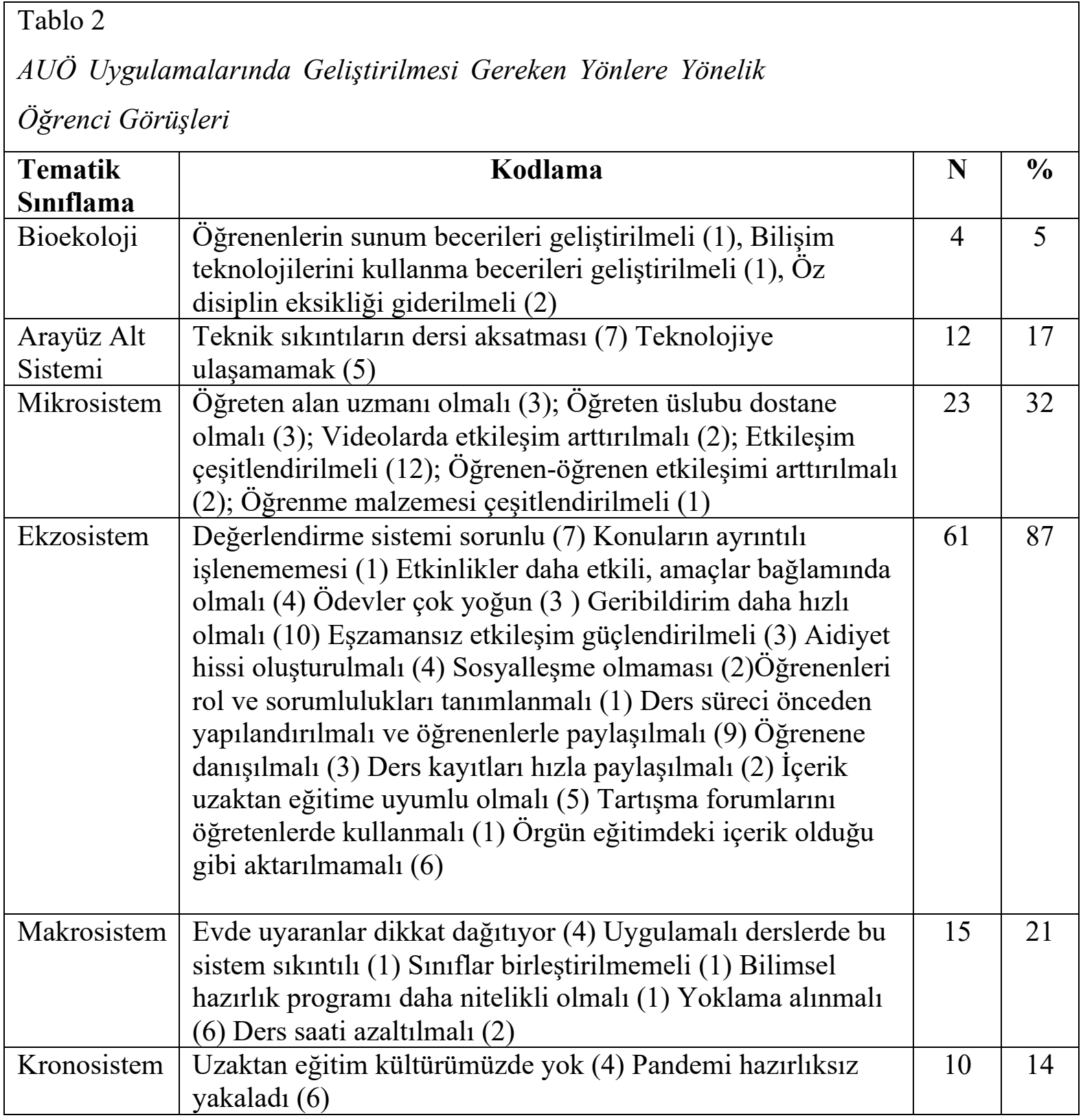


Makrosistem düzeyinde ise, evde uyaranlar dikkat dağıttığı ( $\mathrm{f}=4)$ vurgulanmıştır. Öğrenenlerden biri “Çok fazla uyaranın bulunduğu alanlarda derslere girdiğimiz için, fazlaca dikkat dağınıklığı sorunu yaşayabiliyor" ş̧eklinde düşüncesini ifade etmiştir. Diğer yandan öğrenenler, uygulamalı derslerde bu sistemin sıkıntılı olduğunu (f=1), sınıfların birleştirilmemesinin gerektiği $(\mathrm{f}=1)$, bilimsel hazırlık programının daha nitelikli olmasının önemi ( $\mathrm{f}=1$ ), yoklama alınmasının faydalı olacağ $(\mathrm{f}=6)$, ders saatinin azaltılmasının gerektiğini $(\mathrm{f}=2)$ ifade etmişlerdir.

Kronosistem düzeyinde, uzaktan eğitimin kültürümüzde olmadığı $(\mathrm{f}=4)$ dile getirilmiştir. $\mathrm{Bu}$ düşünce, bir öğrenen tarafından "Uzaktan eğitim kültürümüzün olmaması verimliliği çok etkiliyor ...sistemin verimli kullanılmasını engelliyor" şeklinde ifade edilmiştir. Bunun yanında öğrenenler pandemiye hazırlıksız yakalanıldığını düşünmektedir $(\mathrm{f}=6)$. Bir öğrenen bu düşüncesini “Uzaktan eğitim deneyimininim bana göre en büyük problemi hem ögretmenler hem de öğrencilerin bu duruma hazırlıksı olması ve hala da tam anlamıyla adapte olamamış olmasıdır" şeklinde ifade edilmiştir.

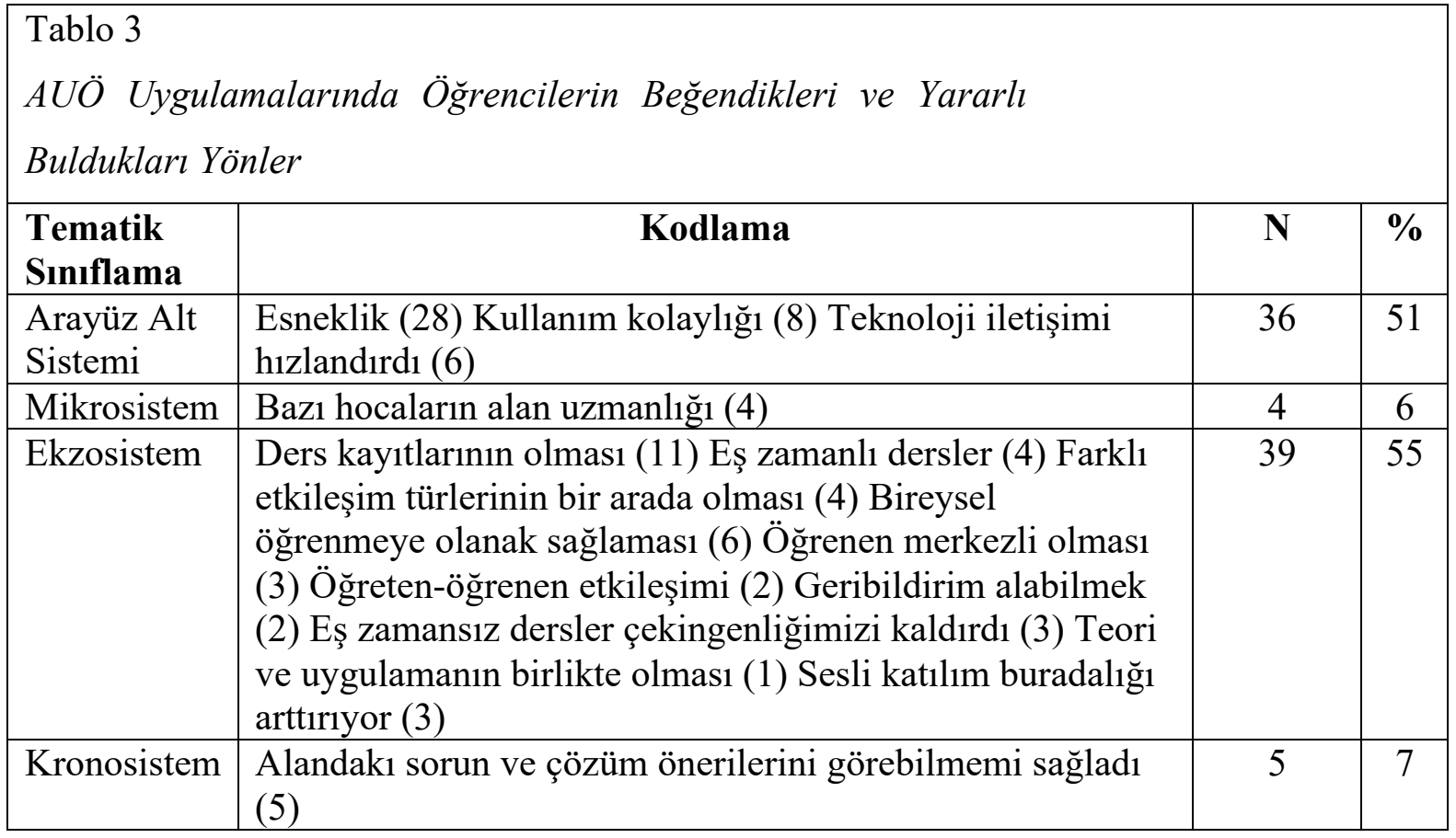

Öte yanda, katılımcı öğrencilerin AUÖ uygulamalarında beğendikleri ve yararlı buldukları yönlere ilişkin görüşleri Tablo 3 'te sunulmuştur. Tablo incelendiğinde Arayüz Alt Sistemi başlığında cevapların \%51'nin ( $\mathrm{f}=36)$ toplandığ 1 görülmektedir. Verilen cevaplara bakıldığında öğrenenler uzaktan eğitim deneyimlerinin olumlu taraflarını esneklik $(\mathrm{f}=28)$, kullanım kolaylığı $(\mathrm{f}=8)$, teknolojinin iletişimi hızlandırması $(\mathrm{f}=6)$ başlıklarıyla ele almışlardır. 
Mikrosistem başlığında ise, bazı hocaların alan uzmanlığının iyi olması ( $\mathrm{f}=4$ ) vurgulanmıştır. Ekzosistem başlığında ise öğrenenler, ders kayıtlarının olmasını ( $\mathrm{f}=11)$, eş zamanlı derslerin varlığını (f=4), farklı etkileşim türlerinin bir arada olmasını $(\mathrm{f}=4)$, bireysel öğrenmeye olanak sağlamasını ( $f=6)$, öğrenen merkezli olmasını $(f=3)$, öğreten-öğrenen etkileşimini $(f=2)$, geribildirim alabilmeyi $(f=2)$, eş zamansız derslerin çekingenliklerini kaldırmasını $(f=3)$, teori ve uygulamanın birlikte olmasını ( $\mathrm{f}=1)$, sesli katılım buradalığı arttırmasını $(\mathrm{f}=3)$ derslerin olumlu özellikleri olarak sıralanmışlardır.

Öğrenenler bu konular hakkında bazı düşünceleri de şöyle olmuştur "Canlı ders uygulamasının bu ĕgitim sürecinin en yararlı kısmı olduğunu düşünüyorum. Öğreten-öğrenen ve öğrenen-ögrrenen etkileşiminin yoğun tutulmasın yararlı ve keyifli buluyorum”, "Zaman ve mekan sınırının olmaması. Bu şekilde çalışırken bile ĕgitim görebiliyorum”, “Ders kayıtlarına istenilen zamanda ulaşılabildiği için ders notu çıkarmak daha kolay olmakta” şeklinde ifade etmişlerdir. Kronosistem başlığında ise verilen cevaplar tüm cevapların \%7'sini (f=5) oluşturmuştur. Cevaplar incelendiğinde, öğrenciler derslerin alandaki sorun ve çözüm önerilerini görme bağlamında ufuklarını açtığını ( $\mathrm{f}=5)$ dile getirmişlerdir.

Son olarak, Tablo 4 öğrenenlerin önümüzdeki dönem dersleri uzaktan alıp almama konusuna ilişkin düşünceleri yer almaktadır. Bu soruya evet yanıtı veren öğrenenler tüm katılımcıların \%77'sini (f=54) oluşturmaktadır. Öğrenenlerin verdikleri cevapları incelediğimizde, öğrenenler ortamın esnek olmasını (11), kolay erişimi (8), hayat akışlarına uygun olduğunu (3), zaman yönetiminin kolay olmasını (6), kaynaklara ulaşımın kolay olduğunu (4), tekrar izleme olanağının olmasını (4), kendi hızında öğrenme olanağı olmasını (3), alanın doğasına uygun olduğunu (4), masrafsız olmasını (1), kendilerine vakit ayırabilmelerini (5), teknolojiyle öğrenmeyi deneyimleyebildiklerini (1), güncellenebilir olmasını (1), kişiliğine uygun olmasını (3) vurgulamışlardır. Öğrenenlerden biri bu konular hakkındaki düşüncesini "Uzaktan eğitimin en yararlı yönü maddiyat açısından kötü durumda olan ögrencilerin şehir dışındaki üniversitelere gitmek zorunda kalmaması...”, şeklinde ifade ederken, bir başka öğrenen "Almak isterim çünkü bu sayede zaman yönetimimi daha kolay yapabiliyorum ” şeklinde ifade etmiştir. 


\section{Tablo 4 \\ Öğrencilerin Gelecekte Dersleri Uzaktan Ĕ̈itim Yoluyla Alma Ĕ̈ilimine Yönelik Görüşleri}

\begin{tabular}{|l|l|c|c|}
\hline Eğilim & \multicolumn{1}{|c|}{ Kodlama } & N & \% \\
\hline Evet & $\begin{array}{l}\text { Esnek (11) Kolay erişim (8) Hayat akışıma uygun (3) } \\
\text { Zaman yönetimi kolay (6) Kaynaklara ulaşım kolay (4) } \\
\text { Tekrar izleme olanağ1 var (4) Kendi hızında öğrenme } \\
\text { olanağ1 var (3) Alanın doğasına uygun (4) Masrafsız (1) } \\
\text { Kendime vakit ayırabiliyorum (5) Teknolojiyle öğrenmeyi } \\
\text { deneyimleyebildim (1) Güncellenebilir (1) Kişiliğime uygun } \\
\text { (3) }\end{array}$ & 54 & $\% 77$ \\
\hline Hayır & $\begin{array}{l}\text { Motive olamıorum (5) Sosyalleşme yok (5) Verimsiz (2) } \\
\text { Okulun kazandırdı̆̆1 disiplini köreltiyor (3) Etkileşim yeterli } \\
\text { değil (1) Öğgrencinin yükü çok (3) Yüz yüzenin sinerjisi yok } \\
\text { (1) }\end{array}$ & 15 & $\% 21$ \\
\hline Harmanlanmış & Teorik dersler uzaktan, uygulamalı dersler için yüz yüze (1) & 1 & $\% 1$ \\
\hline
\end{tabular}

Hayır yanıtını veren öğrenenler, katılımcıların \%21'ini ( $\mathrm{f}=15)$ oluşturmaktadır. Verilen cevapları incelediğimizde öğrenenlerin motive olamıyorum (5,) sosyalleşme yok (5), verimsiz (2), okulun kazandırdığı disiplini köreltiyor (3), etkileşim yeterli değil (1), öğrencinin yükü çok (3), yüz yüzenin sinerjisi yok (1) yanıtlarını verdikleri görülmektedir. Öğrenenler bu düşüncelerini "Hayır. Nedeni disiplin anlayışının yok oluşu ve okulda edinilen alışkanlıkların yok olmasl”, "Gelecekte uzaktan eğitimle ders almak istemem, çünkü kampüsü ve içinde yaşayabildiklerimizi deneyimlemek isterim”, “...bir süre sonra moral ve motivasyonumuzun düşmesiyle verimsiz bir hale dönüşebiliyor" cümleleriyle ifade etmişlerdir.

Harmanlanmış eğitimi tercih edenlerin ise katılımcıların \%1'ini ( $\mathrm{f}=1$ ) oluşturdukları görülmektedir. Onlar da teorik derslerin uzaktan, uygulamalı derslerin yüz yüze olması gerektiğini ( $\mathrm{f}=1$ ) vurgulamışlardır. Öğrenenlerden biri "Teorik dersleri uzaktan almak isterim. Uygulamalı derslerin örgün olmasını isterim" şeklinde ifade etmiştir. 


\section{Tartışma ve Sonuç}

Çalışmanın temel amacı, öğrenenlerin COVIID-19 sırasında uygulanan AUÖ uygulamalarına ilişkin bakış açılarını EST bağlamında tartışmaktır. Bu amaca ulaşmak için öğrenenlere üç soru yöneltilmiştir. İlk soruda eğitimlerine devam ettikleri uzaktan eğitim deneyimlerinin geliştirilmesi gereken yönlerini belirlemeleri, ikinci soruda, bu deneyimlerine ilişkin beğendikleri ve olumlu buldukları tarafların neler olduğunu ifade etmeleri istenmiştir. $\mathrm{Bu}$ iki sorudan alacağımız cevaplarla öğrenenlerin AUÖ konusundaki görüş ve eleştirilerinin EST sürecinin hangi basamağında yoğunlaştı da belirlenmeye çalışılmıştır. Üçüncü soruda, gelecekte uzaktan eğitimle eğitim almayı isteyip istemediklerini nedenleriyle açıklamaları istenmiş ve bu cevaplar EST bağlamında tartışılmaya çalışılmış.

\section{Geliştirilmesi Gereken Yönler}

Öğrenenlerin ilk soruya verdikleri yanıtlar, bioekoloji, arayüz, mikrosistem, ekzosistem, makrosistem ve kronosistem basamaklarında sınıflanmıştır (Şekil 2). Çalışmanın ilk sorusuna yönelik bioekoloji düzeyinde öğrenenler, özyönetim eksikliğini önemli bir sorun olarak dile getirmiştir. Açık ve uzaktan öğrenme ortamlarında öğrenenlerin özyönetim becerilerine sahip olmalarının önemi, farklı çalışmalarda (Kuo, Walker, Schroder ve Belland, 2014; Yükseltürk ve Bulut, 2007) vurgulanmıştır. Bu çalışmalarda, çevrimiçi öğrenme ortamlarının daha esnek, daha fazla öğrenen merkezli olması ve daha fazla otonomi içermesi, özyönetim becerilerine sahip olmayı gerektirdiği dile getirilmiştir. Çevrimiçi ortamlarda öz-yönetimli öğrenenlerin daha başarılı oldukları savı bu araştırmalarla desteklenmiştir. Buna bağlı olarak, öğrenme sürecinde, öğrenenin daha fazla rol almasını gerektiren yaklaşımların öneminin arttığı söylenebilir. Bu bağlamda AUÖ ortamları, hem öğrenenlerin öğrenme sürecinde daha fazla rol almalarını sağlayacak, hem de akranlarıyla etkileşimli ve işbirliği içinde çalışma ortamı sağlayacak şekilde yapılandırılmasının, öğrenenlerin özyönetim becerilerinin gelişmesine katkısının olacağı söylenebilir.

Arayüz alt sisteminde öğrenenler, yaşadıkları teknik sıkıntıların dersleri aksattığı vurgusunu yapmışlardır. Öğrenenler, internet erişimi, altyapı eksikliği ve internet hızından dolayı ortaya yaşadıkları sorunları dile getirmişlerdir. İnternetin yavaş olduğunu, bağlantının sık sık kesildiğini, bağlantının yeterli olmaması nedeniyle ses ve görüntü sorunları yaşadıklarını belirtmişlerdir. AUÖ konusunda yapılan çalışmalarda da öğrenenlerin internete ulaşmada yaşadıkları sorunlar çok sık dile getirilmiştir. (Can, 2020; Başaran ve diğerleri, 2020; Telli Yamamoto ve Altun, 2020). Reimer ve Schleicher'in (2020) Türkiye'nin de yer aldığg 98 
ülkeden uzaktan eğitim ile ilgili kurumlarda çalışan 330 katılımcı ile yaptıkları ankette, katılımcıların \%42'si teknolojik altyapı yetersizliği konusunda sorun yaşadıklarını dile getirmişlerdir. Keskin ve Kaya'da (2020) yaptıkları çalışmada, lisans ve lisansüstü öğrencilerinin yarıdan fazlasının eğitimler sırasında teknik sorunlar yaşadığı görülmektedir. Öte yandan geniş kitlelere yönelik uzaktan eğitim faaliyetlerinin etkili olabilmesi için ekonomi, teknoloji ve eşitlik konuları büyük önem taşımaktadır (Kurubacak ve Yüzer, 2020). Bunun için öncelikle öğrenenlerin uzaktan öğrenme içeriklerine erişim araçlarına sahip olma durumları belirlenmeli ve ihtiyaçların nasıl karşılanacağı konusunda çözüm üretilmelidir. Diğer yandan, teknik sorunlara ilişkin çözüm üretebilmelerine yardımcı olacak, ihtiyaç duyduklarında erişebilecekleri bir destek sisteminin oluşturulmasının da faydalı olacağı düşünülmektedir.

Mikrosistem düzeyinde, öğrenenler etkileşimin çeşitliliğinin arttırılması gerektiğini dile getirmişlerdir. Al-Samarraie ve diğerleri (2017) yaptıkları çalışmada öğrencilerin ilgisini çekecek eğitim materyallerinin, uzaktan eğitimde öğrenmenin sürekliliğinin sağlanmasında önemli olduğunu dile getirmişlerdir. Trust ve Bond'da (2020) düşük kaliteli materyallerin uzaktan eğitime ilişkin olumsuz görüşlerin temelini oluşturabileceğine değinmişlerdir. Diğer yandan yapılan çalışmalar, açık ve uzaktan öğrenme uygulamalarında hem bilişsel hem de sosyal katılımı sağlamak adına farklı etkileşim türlerini destekleyen bir öğrenme sürecini oluşturmasının önemli olduğunu göstermektedir (Hodges, Moore, Lockee, Trust ve Bond, 2020). Ancak yaşadığımız durumun acil olması, hızlı hareket etmeyi, çabuk karar almayı gerektirmiş, ders tasarımı konusunda deneyim ve zamana sahip olunmaması da uzaktan eğitim sürecinin tüm bileşenleriyle işletilmesine engel olmuştur. Öte yandan farklı iletişim araçları ve bu araçların etkileşim unsurlarını bir arada kullanarak teknolojiye ulaşım farklılığının yarattığı eşitsizlikler dengelenmeye çalışılabilir.

Bunun yanında öğrenenlerin ilk soruyla ilgili düşüncelerinin, EST’nin ekzosistem boyutu çerçevesinde yoğunlaştı̆̆ı görülmektedir. Bu konuda öğrenenler özellikle, duruma özgü değerlendirme sisteminin geliştirilmesinin gerektiğini, ders sürecinin önceden planlanmasının çok önemli olduğunu ve geribildirimin daha hızlı olması gerektiğini vurgulamışlardır. Yapılan benzer çalışmalarda da (Bach, Haynes ve Smith, 2007; Can, 2020) AUÖ'de ölçme ve değerlendirme sürecinde sorunlar yaşandığı dile getirilmiş, ölçme ve değerlendirmenin daha sağlıklı yürütülebilmesi için sistemsel olarak ele alınması gerektiği vurgulamıştır. Bu süreçte öğretenlerin sınavları temel değerlendirme aracı olarak gördükleri, bu bağlamda çevrimiçi sınavların nasıl daha güvenli ve gözetimli hale getirileceğine odaklandıkları söylenebilir. Oysa uzaktan öğretimle yürütülen program ve derslerde ölçme-değerlendirme yöntemlerinin sadece 
sınavlarla değil; sürece yayılacak şekilde kurgulanması önemlidir. Çevrimiçi ölçme ve değerlendirme konusunda standartlar belirlenmeli, daha etkili ve elverişli bir değerlendirme ortamı sağlayabilmek adına, öğreneni merkeze alan elektronik ürün, ödev, performans ve etkinlik dosyası gibi süreç odaklı değerlendirme yaklaşımları, akran değerlendirmesi gibi yöntemler kullanılmalıdır. Üniversitelerin kendi içlerinde, çevrim içi sınav merkezleri kurarak değerlendirme süreçlerini daha sistematik hale getirmelerinin de kalıcı bir çözüm olacağ1 düşünülebilir.

Diğer yandan öğrenenler ilk soruyla ilgili olarak, ders sürecinin önceden planlanması ve kendileriyle paylaşılması gerektiğini vurgulamışlardır. $\mathrm{Bu}$ anlamda öğretenlerin ders kazanımlarını ve beklentilerini açık bir şekilde yönergelerle sunmalarının, öğrenenlerin bilişsel bulunurluğunun arttırılmasına yardımcı olacağı düşünülebilir. Diğer yandan öğretenlerin küresel salgın sürecinde duruma çok hızlı uyum sağlamaları, refleks göstermeleri ve uzaktan eğitime uygun derslerin hazırlaması kolay değildir (Telli Yamamoto ve Altun, 2020). Öğretenlerde AUÖ sürecinde, yaşadıkları en büyük sorunun teknolojik alt yapıdan sonra uzaktan öğrenenler için içerik geliştirme olduğunu dile getirmişlerdir (Doğan ve Koçak, 2020). AUÖ uygulamaları için etkili ve verimli içerik yapılarını oluşturabilmek için, öncelikle yüz yüze eğitime göre düzenlenmiş öğretim programlarının, kazanımlarının, içeriklerinin, etkinliklerinin, değerlendirme sürecinin gözden geçirilmesi gerekmektedir. $\mathrm{Bu}$ süreçte öğretenlerin teknolojik, pedagojik alan bilgilerinin de geliştirmeleri konusunda desteğe ihtiyaçlarının olduğu açıktır. Bu bağlamda, eğitim kurumlarında öğrenme tasarımı ve dijital içerik üretim ve denetim birimlerinin kurulmasının faydalı olacağı düşünülmektedir. Bunun için öncelikle öğretenlerin AUÖ sürecinde yaşadıkları zorluklar doğru analiz edilmeli, destek eğitimleri bu ihtiyaçlar doğrultusunda hazırlanmalıdır. Bunun yanında yaşanabilecek benzer kriz durumları için, yüz yüze, harmanlanmış ve uzaktan öğrenme olmak üzere üç yapı için de planlamanın yapılması ve ders içeriklerinin hazırlanmasının gerekli olacağı düşünülmektedir.

Öğrenenlerin ilk soruyla ilgili olarak dile getirdikleri bir diğer konu, geribildirimin daha hızlı olması gerektiğidir. AUÖ uygulamalarına ilişkin yapılan çalışmalarda, yeterli geribildirimin verilmesi, öğretim elemanlarının öğrencilerle kurdukları iletişimde hızlı ve destekleyici olmaları, öğrenenlerin öğrenme sürecinden aldıkları verimi arttırmaktadır (Altun Ekiz, 2020; Arbour, Kaspar ve Teall, 2015; Elcil ve Şahiner, 2013; Karakuş ve Yelken, 2020; Keskin ve Kaya, 2020; Yıldız, 2016). Öte yandan küresel salgın sürecinin birçok eğitim kurumunu gerek pedagojik gerekse teknolojik olarak hazırlıksız yakaladığı görülmektedir. $\mathrm{Bu}$ nedenle örgün ortamda işleyen bir sürecin çok hızlı bir şekilde çevrimiçi ortama aktarılması ve 
önemli bir bileşen olan geribildirim sürecinin sağlıklı işletilebilmesi konusunda sıkıntıların yaşanması beklenen bir sonuç olacaktır.

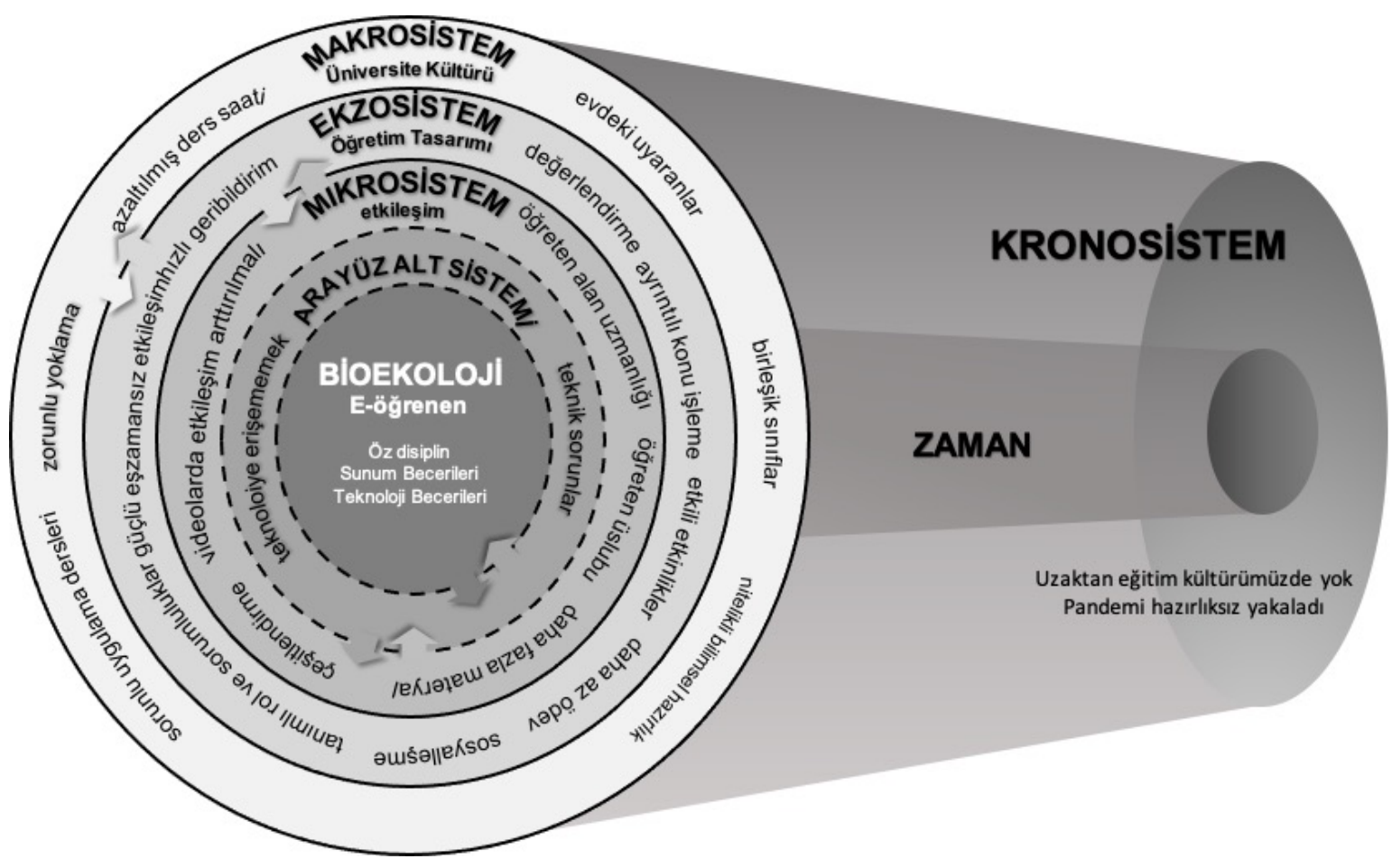

Şekil 2. AUÖ’nün geliştirilmesi gereken yönlerinin Ekolojik Sistem Teorisine uyarlanması

Makrosistem düzeyinde öğrenenler yoğun olarak, evdeki uyaranların dikkati dağıttığ konusuna vurgu yapılmışlardır. Alanyazın incelendiğinde, benzer sonuçları ortaya koyan çalışmaların olduğu görülmektedir (Akgün, Güleç ve Topal, 2013; Gillies, 2008; Hannay ve Newvine, 2006). Bu çalışmalarda öğrenenler, zaman yönetimi ve motivasyonu korumayla ilgili yaşadıkları zorlukları dile getirmişlerdir. Küresel salgın sürecinde AUÖ'de yaşanan en önemli sorunlardan biri, kendi öğrenme planını yapamayan, zaman yönetimi konusunda sorun yaşayan öğrencilerin, bu süreci evde geçiriyor olmaları dolayısıyla motivasyonlarının düşmesidir. AUÖ’de etkileşimin yüz yüzeye göre daha kısıtlı olması sebebiyle, öğrenenler kendi öğrenmelerinden sorumlu olmaktadır. Bu bağlamda sınıf ortamında öğrenmeye alışkın öğrencilerin bu süreci evde yürütmeye çalışmalarının, motivasyonlarını düşürdüğü söylenebilir.

Kronosistem düzeyinde ise öğrenenler, küresel salgına hazırlıksız yakalanıldığını düşünmektedir. Bu dönemde, çok kısa bir sürede yüz yüze eğitim uygulamalarından AUÖ uygulamalarına geçilmiş, bu hızlı geçiş süreci, öğreticileri ve öğrenenleri hazırlıksız yakalamıştır. Gerek öğreticiler gerekse öğrenenler alışık oldukları yüz yüze eğitimden, belki 
de uygulamaya dönük çok da fazla deneyimi olmadıkları bir sisteme geçmek zorunda kalmıştır. $\mathrm{Bu}$ durum başta öğretenler, öğrenenler ve veliler olmak üzere tüm paydaşlar üzerinde ciddi bir tedirginlik meydana getirmiştir. Özellikle öğretenlerin uzaktan eğitim konusundaki deneyimsizliği, öğrenenlerin yeni sisteme uyum sorunları ve öğrenen başarılarının nasıl değerlendirileceği soruları, bu tedirginliği arttırmış olabilir. Bunun yanında kurumların yüzleştiği çok önemli bir sorun, internet üzerinden yapılacak uzaktan eğitim altyapısına sahip olmamaları veya sahip oldukları durumlarda bile bu konuda daha önce hazırlık yapılmamış olmasıdır (Telli Yamamoto ve Altun, 2020). Bu anlamda altyapı eksikliklerinin giderilmesi yanında yüz yüze eğitime göre düzenlenmiş öğretim programlarının kazanımlar, kazanımlara yönelik içerikler, etkinlikler, değerlendirme süreçleri açısından gözden geçirilmesi gerekmektedir. Yaşanan deneyimden yola çıkarak gerek yüz yüze gerek uzaktan gerekse de harmanlanmış ortamlar için öğrenme süreçlerinin planlanmasının faydalı olacağı açıktır.

\section{Güçlü ve Yararlı Bulunan Yönler}

Çalışmanın ikinci sorusunda, öğrenenlerin, uzaktan eğitim deneyimlerine ilişkin en beğendikleri yönler belirlenmeye çalışılmıştır. Burada da öğrenenlerin verdikleri cevaplar arayüz, mikrosistem, ekzosistem ve kronosistem düzeylerinde sınıflanmıştır.

Arayüz alt sisteminde, öğrenenlerin büyük bölümünün esneklik kavramına vurgu yaptıkları görülmektedir. AUÖ uygulamalarına yönelik araştırmalarda da (Al-Rabiaah, 2020; Craig vd., 2020; Liguori ve Winkler, 2020; P1nar ve Döner, 2020; Selwyn,2020; Serçemeli ve Kurnaz, 2020; Tekdal ve Yiğen, 2020; Toquero, 2020) esneklik vurgusu öne çıkmıştır. Çalışmalarda ders kayıtlarının ve materyallerin uzaktan erişime açılmasının, hem öğrencilerin kendi öğrenme hızlarında ilerlemelerine destek olması, hem de kalıcılığg arttırması yönündeki avantajları dile getirilmiştir. Her zaman ve her yerde derse ulaşabilmenin çevrimiçi öğrenmenin önemli bir bileşeni olduğu vurgulanmıştır. 


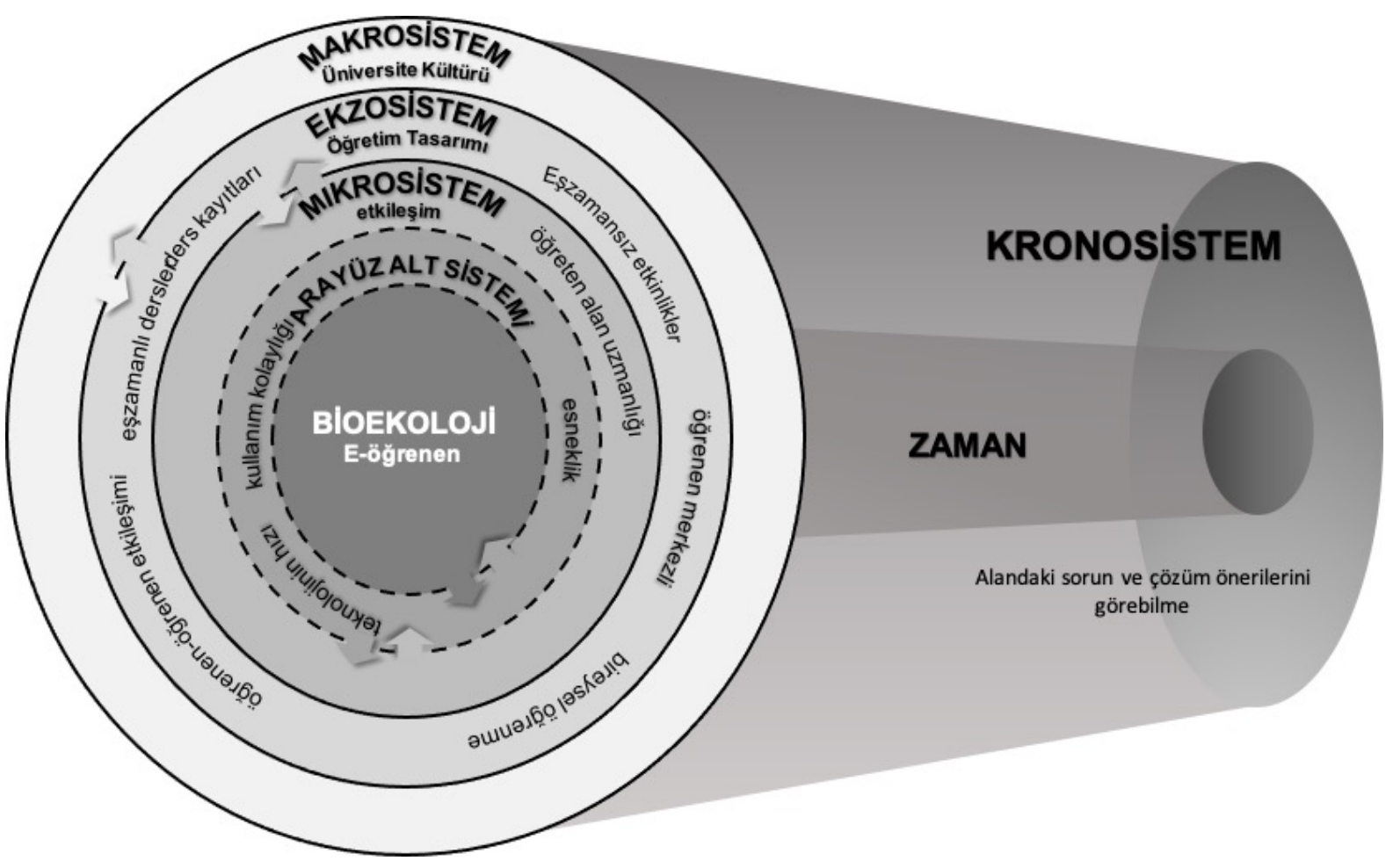

Şekil 3. AUÖ’nün güçlü ve yararlı bulunan yönlerinin Ekolojik Sistem Teorisine uyarlanması

$\mathrm{Bu}$ soruya verilen yanıtlarda ilk soruda olduğu gibi ekzosistem düzeyinde yoğunlaşmıştır. Ekzosistem seviyesinde öğrenenler, ders kayıtlarının olmasının yararına özellikle vurgu yapmışlardır. Yapılan çalışmalarda da ders kayıtlarının ve materyallerin uzaktan erişime açılmasının, hem öğrenenlerin kendi öğrenme hızlarında ilerlemelerine destek olduğunu hem de öğrenmenin kalıcılığını arttırdığını göstermiştir (Kocatürk ve Uşun, 2020; Pınar ve Döner, 2020; Yolcu, 2020). Çalışmada, öğretenlerin çoğunlukla eşzamanlı ders anlatımı ve nadiren eşzamansız etkinlikleri kullanıldığı, öğrenenlerin de oturumlara katılmak yerine ders kayıtlarını izlemeyi tercih ettiklerini görülmektedir. Öğretenlerin derslerinde eşzamansız derslere yoğunlaşmamaları, küresel salgın sürecine hazırlıksız yakalanmalarından ve AUÖ’yi kısa sürede sona erecek geçici bir durum olarak görmelerinden kaynaklanabilir. Öte yandan, açık ve uzaktan öğrenme uygulamalarında esnekliğin sürdürülebilirlik için önemli bir bileşen olduğu düşünüldüğünde, eşzamansız katılımı destekleyecek etkinliklerin tasarlanmasının oldukça önemli olduğu söylenebilir. Son olarak mikrosistem düzeyinde hocaların alan uzmanlıklarına ilişkin beğenilerini dile getirdikleri görülmektedir. Kronosistem düzeyinde ise öğrenenler, AUÖ sürecinde alandaki sorun ve çözüm önerilerini görebilmelerini sağladığ 1 vurgulanmıştır.

Öte yanda, öğrenenlerin cevaplarının EST'nin hangi düzeyinde yoğunlaştığı da belirlenmeye çalışılmıştır. Yapılan analiz, sonunda öğrenenlerin AUÖ programına ilişkin görüş 
ve önerilerinin ekzosistem düzeyinde yoğunlaştığı görülmektedir. Diğer bir değişle öğrenenlerin programın işleyiş sürecine ilişkin beğeni ve eleştirilerinin; konuların işlenmesi, etkinliklerin yapılandırılması, geribildirim, değerlendirme süreci gibi öğretim tasarımı boyutuna ilişkin olduğu görülmektedir. Öğretim tasarımı, etkili bir öğrenme sürecini sağlamak için sürekli planlama, tasarım, geliştirme ve değerlendirme yapmayı gerektiren dinamik bir süreçtir (Morrison, Ross, Kemp ve Kalman, 2010). Ekzosistem, çevrimiçi öğrenme ortamlarındaki bu dinamik yönelimin gerçekleştiği düzeydir. Diğer bir değişle, ekzosistemde öğrenenlerin performanslarını ve yeterliklerini artırmak için, öğrenme sürecinin planlanmasına, geliştirilmesine, değerlendirilmesine ve sürdürülmesine yönelik planlamalar yapılır. Ekolojik bir sistem olarak AUÖ ortamında öğrenen davranışlarını anlayabilmek ve öğrenme sürecini yapılandırabilmek için her bir katmanın birbirini etkilediği unutulmamalıdır. İdeal öğrenme ortamlarının yaratılması ve yeniliklerin etkili bir şekilde uygulanabilmesi için, AUÖ sisteminin her bileşeninin birlikte hareket etmesi önemlidir. Sistemi oluşturan basamaklar arasındaki tutarlılık ne kadar fazla ise, sistemin öğrenme sürecindeki etkisi de o kadar olumlu olacaktır. Bu bağlamda, etkili bir AUÖ süreci inşa edebilmek için, bioekolojiden kronosistem düzeyine kadar her bir basamağın karşılıklı etkileşim içinde olduğu, birbirini etkilediği unutulmamalıdır. Bu nedenle küresel salgın sürecinin, öğrenen algısı, teknolojik altyapı, öğrenenin etkileşim kurduğu çevresi ve etkileşim biçimi, üniversite yönetiminin aldığı kararlar gibi, öğretim tasarımı sürecinde alınacak kararları etkileyerek yönlendireceği açıktır. Bu nedenle, AUÖ için ders içeriklerini planlarken bütünsel bir sistem oluşturmak ve doğru öğretim tasarımını kurgulamak gerekir. EST'nin de çevrimiçi öğrenme ortamlarında öğrenenlerin öğrenme sürecini iyileştirmek için politika, araştırma ve uygulamaya rehberlik edecek birleştirici bir teorik çerçeve sunabileceği düşünülmektedir.

\section{Gelecek Eğilimleri}

Çalışmanın üçüncü olarak, öğrenenlere önümüzdeki dönem uzaktan eğitimle eğitim almak isteyip istemedikleri sorulmuştur. Bu soruya evet diyen öğrenenlerin temel vurgularının esneklik ve kolay erişim üzerine olduğu görülmüştür. Ayrıca öğrenenler bu sistemde zaman yönetiminin kolay olduğunu ve kendilerine vakit ayırabilme firsatı bulduklarını dile getirmişlerdir. Yapılan çalışmalarda da (Fidalgo vd., 2020; Jung ve Rhea, 2000; OECD, 2020) AUÖ’de öğrenenlerin zamanlarını daha verimli kullanabildikleri dile getirilmiştir. Bunun bir sebebi de şehir dışından gelen öğrenenlerin, küresel salgın sürecinde eğitimi evden takip etmeleri sebebiyle yolda geçirecekleri zamandan tasarruf ettiklerini düşünmeleridir. 
Hayır yanıtını veren öğrenenlerin gerekçeleri ise, motive olamamaları, sosyalleşmenin olmaması üzerine yoğunlaşmıştır. Gençlerin akranlarıyla sosyalleşme firsatı buldukları okullardan uzak kalmaları, sosyal izolasyonu beraberinde getirmiştir (Can, 2020; Chang ve Satako, 2020). Küresel salgın dönemi bize bir kez daha, uzaktan eğitim sürecinde, okulun sadece eğitim değil; sosyalleşmeyi içeren toplumsal bir mekan olduğunu göstermiştir (Anderson, 2020). Harmanlanmış cevabını verenler ise teorik derslerin uzaktan, uygulamalı derslerin yüz yüze yapılması gerektiğini dile getirmişlerdir.

\section{Öneriler}

$\mathrm{Bu}$ teorik modelin öğretim tasarımcıları başta olmak üzere sürecin planlayıcı ve uygulayıcıları için önemli bir işlev göreceği düşünülmektedir. Hem uygulama yapabilmek hem de uygulamaya dönük politikalar geliştirilebilmek için, AUÖ dönemine yönelik nicel, nitel ve karma araştırmaların yapılması ve bu araştırmaların tüm paydaşlar tarafından ele alınması gerekmektedir. Türkiye' de eğitim kurumları daha önce benzer bir kriz dönemini yaşamadıkları için küresel salgın sürecine hazırlıksız yakalanmışlardır. AUÖ sürecinde ders tasarımı, içerik geliştirme, teknoloji kullanımı, değerlendirme sürecinde yaşanan sorunlar, uzun vadede uzaktan eğitime karşı önyargı ve direnç oluşmasına neden olabilir. Bu önyargı oluşumunu önleyebilmek için, AUÖ sürecinde gerçekleştirilen özellikle etkili ve doğru uygulamaların incelenmesi önemli bir çıkış noktası olacaktır. Küresel salgının kontrol altına alınmasından sonra gelecek dönemde, uzaktan öğrenme uygulamalarının kullanımının ne ölçüde ve ne şekilde devam edeceği, büyük ölçüde bu süreçteki deneyimlerden elde edilecek verilere ve deneyimlerden çıkarılacak derslere göre şekillenecektir. Bugün yaşadıklarımız, uzaktan öğrenme sürecinde kullanılan araçlar kadar, öğrenenlerin bu araçlara ve bu araçlar aracıllı̆̆ıyla sunulacak nitelikli içeriğge erişiminin sağlanmasının etkili bir uzaktan öğrenme sürecinin belirleyicisi olduğunu göstermiştir. AUÖ uygulamaları bize, sistemin iyileşmesi, esnekliği ve yeniden yapılandırılması için geleceğe dönük çözüm önerileri geliştirebilme firsatı sunmuştur. Yeterli hazırlık yapılamadan, bir krizle başlayan AUÖ uygulamaları sonrasında, bu uygulamaları irdeleyerek kazanacağımız tecrübe ile, krizi fırsata dönüştürerek etkili bir harmanlanmış eğitim modelinin nasıl olması gerektiği konusunda ip uçlarına ulaşabiliriz. Ancak bu şekilde kısa vadeli çözüm odaklı yaklaşımlardan yola çıkarak, uzun vadeli anlayış geliştirebilmek, politikalar üretebilmek mümkün olacaktır. Edinilen bu tecrübe ve birikim, çevrimiçi öğrenme ekosisteminde yönetsel, teknoloji ve pedagoji ilişkisini doğru bir şekilde ortaya konulmasına yardımcı olacaktır. 


\section{Kaynakça}

Akgün, Ö. E., Güleç, İ. \& Topal, M. (2013). Lisansüstü uzaktan eğitim öğrencilerinin uzaktan eğitime yönelik görüşleri. VI. Ulusal Lisansüstü Eğitim Sempozyumu, Sakarya Üniversitesi, Sakarya.

Akmeşe, H., \& Ilgaz, A. (2020). Yeni koronavirüs (Kovid-19) pandemisinin Hong Kong'a gelen turist sayısı üzerindeki etkilerinin son beş yılın verilerine göre karşılaştırmalı bir analizi. MANAS Sosyal Araştırmalar Dergisi. 2020 Cilt: 9 Sayı: 4

Al-Rabiaah, A., Temsah, M.H., \& Al-Eyadhy, A.A., (2020). Middle east respiratory syndrome corona virus (mers-cov) associated stress among medical students at a university teaching hospital in Saudi Arabia. Journal Infect Public Health, 13, 687-691.

Altiparmak, K., Kurt, İ. D. \& Kapidere, M. (2011). E-learning and open source code management systems in education. Akademik Bilisim'11 - XIII. Akademik Bilisim Konferans1 Bildirileri, Inonu Universitesi, http://ab.org.tr/ab11/kitap/altiparmak kurt_AB11.pdf.Erișim Erişim Tarihi:01.01.2021

Altun Ekiz, M. (2020). Beden eğitimi ve spor yüksekokulu öğrencilerinin karantina dönemindeki uzaktan eğitim ile ilgili görüşleri (nitel bir araştırma). Journal of Sport and Recreation Researches, 2(11),1-13.

Altun, D. (2020). Klsa vadede hepimizin Ihtiyacı - canlı ve Toplu iletişim. https://www.linkedin.com/pulse/k\%C4\%B1sa-vadede-hepimizinihtiyac $\% \mathrm{C} 4 \% \mathrm{~B} 1$ canl $\% \mathrm{C} 4 \% \mathrm{~B} 1-$ ve-toplu-ileti $\% \mathrm{C} 5 \% 9$ Fim-altun Erişim Tarihi:22.11.2020

Anderson, J. (2020). Brave new world the coronavirus pandemic is reshaping education. https://qz.com/1826369/how-coronavirus-is-changing-education/

Andoh, R.P.K., Appiah, R., \& Agyei, P.M. (2020). Postgraduate distance education in University of Cape Coast, Ghana: Students' perspectives. International Review of Research in Open and Distributed Learning, 21(2), 118-135.

Arbour, M., Kaspar, R.W. \& Teall, A.M. (2015). Strategies to promote cultural competence in distance education. Journal of Transcultural Nursing, 26(4), 436- 440.

Bach, S., Haynes, P., \& Smith, J. L. (2007). Online learning and teaching in higher education (p. 209). McGraw-Hill International

Başaran, M., Doğan, E.,Karaoğlu, E., \& Şahin, E. (2020). Pandemi sürecinin getirisi olan uzaktan eğitimin etkililiği üzerine bir çalışma. Academia Ĕ̆itim Araştırmaları Dergisi. 5(2), 368-397. 
Berk, L.E. (2000). Child development (5th ed.). Boston: Allynand Bacon Bronfenbrenner, 1979.

Bergdahl, N., \& Nouri, J. (2020). Covid-19 and crisis-promted distance education in Sweden. Technology, Knowledge and Learning, 0123456789.

Bronfenbrenner, U. (1977). Toward an experimen- tal ecology of human development. The American Psychologist, 32(7), 513-531. doi:10.1037/0003-066X.32.7.513

Bronfenbrenner, U. (1979). The ecology of human development: Experiments by nature and design. Cambridge, MA: Harvard University Press.

Bronfenbrenner, U. (1988). Interacting systems in human development. Research paradigms: Present and future. N. Bolger, A. Caspi, G. Downey ve M. Moorehouse (Ed.), Persons in Context: Developmental Processes içinde (s. 25-49). New York: Cambridge University Pres.

Bronfenbrenner, U. (1989). Ecological systems theory. Annals of Child Development, 6, 18724.

Bronfenbrenner, U. (1995). Developmental ecol- ogy through space and time: A future perspective. In P. Moen \& G. H. Elder Jr., (Eds.), Examining lives in context: Perspectives on the ecology of human development (pp. 619-647). Washing- ton, DC: American Psychological Association. doi:10.1037/10176-018

Bronfenbrenner, U. (2004).Making human beings human: bioecological perspectives on human development. USA: SAGE Publications, Inc.

Bronfenbrenner, U. (2005). Making human beings human: Bioecological perspectives of human development. Thousand Oaks, CA: Sage.

Bronfenbrenner, U. \& Morris, P. A. (2006). The bioecological model of human development. In Damon, W. \&Lerner, R. M. (Eds), Handbook of childpsychology. New York: John Wiley\&Sons.

Bronfenbrenner, U. (2009). Urie Bronfenbrenner'in insan gelişiminde çevresel yaklaşımı. (Çev. Şen-Beyazyürek). Seyhan Rehberlik ve Araştırma Merkezi. Adana.

Büyüköztürk, Ş., Kılıç Çakmak, E., Akgün, Ö.E., Karadeniz, Ş. \& Demirel F. (2016). Bilimsel Araştırma Yöntemleri (20. Baskı), Pegem Akademi, Ankara.

Can, E. (2020). Coronavirüs (Covid-19) pandemisi ve pedagojik yansımaları: Türkiye'de açık ve uzaktan eğitim uygulamaları. Açıköğretim Uygulamaları ve Araştırmaları Dergisi, $6(2) .11-53$. 
Champaign, J. \& Cohen, R. (2011).Exploring the effects of errors in assessment and time requirements of learning objects in a peer-based intelligent tutoring system, in FLAIRS Conference, pp.495-500.

Chang, G.C. \& Satako, Y. (2020). How are countries addressing the Covid-19 challenges in education? Anapshot of policy measures. https:/gemreportunesco.wordpress.com/2020/03/24/how-are-countries-addressingthecovid-19-challenges-in-education-a-snapshot-of-policy-measures/, Erişim Tarihi: 26. 03.2020

Chuck, R. C., Clifton, G. T., Peace, K. M., Propper, B. W., Hale, D. F., Alseidi, A. A., \& Vreeland, T. J. (2020). Using technology to maintain the education of residents during the COVID-19 pandemic. Journal of Surgical Education. doi:10.1016/j.jsurg.

Cohen, L., Manion, L. \& Morrison, K. (2007). Research methods in education (6th ed.). New York, NY: Routledge.

Craig, A. T., Heywood, A. E., \& Hall, J. (2020). Risk of COVID-19 importation to the Pacific islands through global air travel, Epidemiology \& Infection, 1-16.

Creswell, J. W. (2015). A concise introduction to mixed methods research. Thousand Oaks, CA: Sage.

Çağlar, C. (2010). Karma eğitim sisteminin öğrenci görüşleri ile değerlendirilmesi (Sakarya Üniversitesi Örneği) (Yayınlanmamış Yüksek Lisans Tezi). Sakarya Üniversitesi, Sosyal Bilimleri Enstitüsü, Sakarya.

Devran, Y.\& Elitaş, T. (2016). Uzaktan eğitim: Fırsatlar ve tehditler. Online Academic Journal of Information Technology, 8(27),31-40.

Durak, G.,Çankaya, S.,\& İzmirli, S.(2020). COVID-19 Pandemi döneminde Türkiye'deki üniversitelerin uzaktan eğitim sistemlerinin incelenmesi. Necatibey Eğitim Fakültesi Elektronik Fen ve Matematik Ĕ̈itimi Dergisi 14(1), 787-809.

Edelhauser, E.\& Lupu-Dima, L. (2020). Is Romania Prepared for eLearning during the COVID-19 Pandemic? Sustainability, 12(13), 1-29.

Elcil, Ş. \& Sözen Şahiner, D. (2013). Uzaktan eğitimde iletişimsel engeller. Sosyal ve Beşeri Bilimler Dergisi, 5(2),525-537.

Erfidan, A. (2019). Derslerin Uzaktan Eğitim Yoluyla Verilmesiyle İlgili Öğretim Elemanı Ve Öğrenci Görüşleri: Balıkesir Üniversitesi Örneği. Yüksek Lisans Tezi, Balıkesir Üniversitesi, Fen Bilimleri Enstitüsü, Balıkesir. 
Fidalgo, P., Thormann, J., Kulyk, O., \& Lencastre, J.A., (2020). Students' perceptions on distance education: A multinational study. International Journal of Educational Technology in Higher Education. 17, Article number: 18

Gillies, D.(2008). Student perspectives on videoconferencing in teacher education at a distance. Distance Education 29(1).

Golden, C. (2020). Remote teaching: The glass half-full. Educause Review. https://er.educause.edu/ blogs/2020/3/remote-teaching-the-glass-half-full

Greenberg, M. T., Domitrovich, C., \& Bumbarger, B. (2001). The prevention of mental disorders in school-aged children: Current state of the field. Prevention \& Treatment, 4 , 1a. https://doi.org/10.1037/1522-3736.4.1.41a

Hannay, M. (2006). Perceptions of distance learning: A comparison of online and traditional learning. MERLOT Journal of Online Learning and Teaching, 2(1), 1-11.

Hatice, G., B., \& Tüzün, H. (2015). Yükseköğretim kurumları web tabanlı uzaktan eğitim programlarında yaşanan sorunlar. AUAd 1(3), 26-50.

Hodges, C., Moore, S., Lockee, B., Trust, T., \& Bond, A. (2020). The difference between emergency remote teaching and online learning. Educause Review. https://er.educause.edu/articles/2020/3/thedifference-between-emergency-remoteteaching-and-online-learning

Al-Samarraie, H.,Teng B. K., Alzahrani, A.,İ, \& Alalwan, N. (2017). E-learning continuance satisfaction in higher education: a unified perspective from instructors and students, Studies in Higher Education, DOI: 10.1080/03075079.2017.1298088

Isman, A. (2011). Instructional Design in Education: New Model. Turkish Online Journal of Educational Technology - TOJET, 10(1), 136 - 142.

Johnson, G. M. (2010). Internet use and child development: The techno-microsystem. [AS B]. Australian Journal of Educational and Develop- mental Psychology, 10, 32-43.

Johnson, G. M. (2014). The ecology of interac- tive learning environments: Situating traditional theory. Interactive Learning Environments, 22(3), 298-308. doi:10.1080/10494820.2011.649768

Johnson, G. M., \& Puplampu, P. (2008). Internet use during childhood and the ecological techno- subsystem. Canadian Journal of Learning and Technology, 34, 19-28.

Johnson, E. S. (2008). Ecological systems and complexity theory: Toward an alternative model of accountability in education. Complicity: An International Journal of Complexity and Education, 5(1), 1-10. 
Johnson, G., M., \& Cooke, A.(2020). An Ecological Model of Student Interaction in Online Learning Environments. In book: Multicultural Instructional Design (pp.387-415)

Johnson, D. W., \& Johnson, R. T. (2008). Social interdependence theory and cooperative learning: The teacher's role. In Gillies, R. M., Ashman, A. \& Terwel, J. (Eds.). Teacher's Role in Implementing Cooperative Learning in the Classroom (pp.9-37). New York, U.S.A: Springer. http://dx.doi.org/10.1007/978-0-387-70892-8_1

Jung, I., \& Rhea, I. (2000). Effectiveness and cost-effectiveness of online education: A review of the literature. Educational Technology, 40(4), 57-60.

Karakuş, İ. \& Yanpar, Y.,T. (2020). Uzaktan eğitim alan üniversite öğrencilerinin sosyal bulunuşluk ile işlemsel uzaklıkları arasındaki ilişkinin incelenmesi. Kastamonu Ĕgitim Dergisi, 28(1),186-201.

Keskin, M. \& Özer K., D. (2020). Covid-19 sürecinde öğrencilerin web tabanlı uzaktan eğitime yönelik geri bildirimlerinin değerlendirilmesi. İzmir Kâtip Çelebi Üniversitesi Sağlık Bilimleri Fakültesi Dergisi, 5(2), 59-67.

Kocatürk Kapucu, N. \& Uşun, S. (2020). Üniversitelerde ortak zorunlu derslerin öğretiminde uzaktan eğitim uygulamaları. Açıköğretim Uygulamaları ve Araştırma Dergisi, 6(1), 827.

Koçoğlu, E., Ulu Kalın, Ö., Tekdal, D. \& Yiğen, V. (2020). Covid-19 Pandemi Sürecinde Türkiye'deki Eğitime Bakış. International Social Sciences Studies Journal, (eISSN:2587-1587) Vol:6, Issue: 65; pp:2956-2966

Kuo, Y.C., Walker, A., Belland, B., Schroder, K. \& Kuo, Y.T. (2014). A case study of integrating Interwise: Interaction, internet self-efficacy, and satisfaction in synchronous online learning environments. The International Review of Research in Open and Distributed Learning, 15(1), Athabasca University Press. from https://www.learntechlib.org/p/148195/.Erișim Tarihi:28.05.2021

Kurubacak, G. \& Yüzer, T.V. (2004). The building of knowledge networks withiInteractiver radio programs in distance education systems. In J. Nall \& R. Robson (Eds.), Proceedings of E-Learn 2004--World Conference on E-Learning in Corporate, Government, Healthcare, and Higher Education (pp. 2360-2367). Washington, DC, USA: Association for the Advancement of Computing in Education (AACE). Retrieved April 8, 2020 from https://www.learntechlib.org/primary/p/11233/. 
Liguori, E. W., \& Winkler, C. (2020). Challenges and opportunities for entrepreneurship education following the COVID-19 pandemic. Entrepreneurship Education and Pedagogy. Retrieved from: https://doi.org/10.1177/2515127420916738.

McCalla, G. (2004). The ecological approach to the design of e-learning environments: Purposebased capture and use of information about learners. Journal of Interactive Media in Education, http://www-jime.open.ac.uk/2004/7/ . Erişim Tarihi:26.01.2021.

Merriam, S. B. (2018). Qualitative research and case study applications in education. San Francisco, CA: Jossey-Bass.

Midkiff, S.,F. \& Dasilve, L.A.(2000). Leveraging the web for synchronous versus asynchronous distance learning. International Conference on Engineering Education içinde (ss. 14-18).

Miles, M.B. \& Huberman, A.M. (1994). Qualitative Data Analysis: An Expanded Sourcebook, Sage

Morrison, G.R., Ross, S.M., Kemp, J. E., \& Kalman, H. (2010). Designing effective instruction. John Wiley \& Sons.

Oliveira M.M.S., Penedo A.S.T. \& Pereira V.S. (2018). Distance Education: Advantages and disadvantages of the point of view of education and society. Dialogia, 29, 139-152. DOI: 10.5585/Dialogia.n29.7661

OECD. (2020). School education during Covid-19 were teachers and students ready? Country note: Turkey. http://www.oecd.org/education/Turkey-coronavirus-education-countrynote.pdf Erişim Tarihi:11.02.2021

Paquette, D. \& Ryan, J. (2001). Bronfenbrenner's ecological systems theory. http://people.usd.edu/ mremund/bronfa.pdf . Erişim tarihi: 12.03.2021.

Patton, M.Q. (1990) Qualitative evaluation and research methods. 2nd ed., Sage Publications, Newbury Park.

Pınar, M.A., \& Dönel, A.G. (2020). Covid-19 salgını sürecinde fen bilimleri dersinin uzaktan eğitim ile verilmesine yönelik öğrenci görüşleri. Journal of Current Researches on Social Sciences, 10(2), 461-486.

Selwyn. N. (2020). After COVID-19: The longer-term impacts of the coronavirus crisis on education. Melbourne: Monash University. https://educationfutures.monash.edu/all\%2D\%2D-present/after-covid19 . Erişim Tarihi: 19. 12.2020 
Serçemeli, M., \& Kurnaz, E. (2020). Covid-19 pandemi döneminde öğrencilerin uzaktan eğitim ve uzaktan muhasebe eğitimine yönelik bakış açıları üzerine bir araştırma. Uluslararası Sosyal Bilimler Akademik Araştırmalar Dergisi, 4(1),40-53

Sheridan, S. M., Warnes, E. D., Cowan, R. J., Schemm, A. V., \& Clarke, B. L. (2004). Familycentered positive psychology: Focusing on strengths to build student success. Psychology in the Schools, 41(1), 7-17.

Swick, KJ., \& Williams R (2006). An Analysis of Bronfenbrenner's Bio-Ecological Perspective for EARLY Childhood Educators: Implications for Working with Families Experiencing Stress. Early Childhood Education Journal, 33 (5).

Toquero, C.M. (2020). Emergency remote teaching amid COVID-19: the turning point. Asian Journal of Distance Education, 15(1), 185-188. https://doi.org/10.5281/zenodo.3881748

UNESCO. (2020). COVID-19 : Recommendations to plan distance learning solutions. https://en.unesco.org/news/covid-19-10-recommendations-plan-distance-learning solutions,

Yamamoto, G.T. \&Altun, D. (2020). Coronavirüs ve çevrimiçi(online) eğitimin önlenemeyen yükselişi. Üniversite Araştırmaları Dergisi, 3(1), 25-34.

Yıldırım A, \& Şimşek H. (2013). Sosyal bilimlerde nitel araştırma yöntemleri. (9. Baskı). Ankara: Seçkin.

Yıldız, C.D. \& Dönmez, B. (2019). Okullarda örgütsel dertleşmeye ilişkin öğretmen görüşleri. Manas Sosyal Araştırmalar Dergisi, 8(4), 3214-3231.

Yıldız, S. (2016). Pedogojik formasyon eğitimi alan öğrencilerin uzaktan eğitime yönelik tutumları. Bolu Abant İzzet Baysal Üniversitesi Sosyal Bilimler Enstitüsü Dergisi, 16(1), 301-329.

Yolcu, H.H. (2020). Koronavirüs (covid-19) pandemi sürecinde sınıf öğretmeni adaylarının uzaktan eğitim deneyimleri. Açıköğretim Uygulamaları ve Araştırma Dergisi, 6(4), 237250.

YÖK. (2020). YÖK dersleri platformuna ögrencilerden yoğun ilgi. https://shorturl.at/jmzAU adresine 03.04.2020 tarihinde erişilmiştir.

Yükseltürk, E., \& Bulut, S. (2007). Predictors for student success in an online course. Educational Technology \& Society, 10(2), 71-83. 


\section{Yazar Hakkında}

\section{Doç. Dr. İrem ERDEM AYDIN}

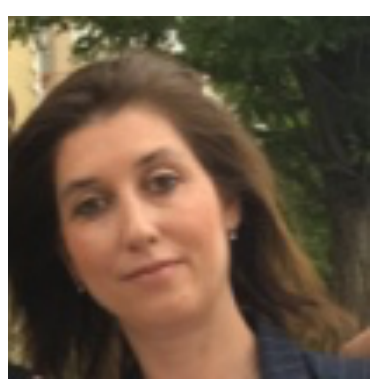

Doç. Dr. İrem ERDEM AYDIN, lisans öğrenimini 1998 yılında Anadolu Üniversitesi İletişim Bilimleri Fakültesi, Eğitim İletişimi ve Planlamas1 bölümünde tamamlamıştır. Yüksek lisans eğitimini Anadolu Üniversitesi Sosyal Bilimler Enstitüsü Uzaktan Eğitim Ana Bilim Dalı'nda, doktora eğitimini Anadolu Üniversitesi Sosyal Bilimler Enstitüsü İletişim Bölümünde almıştır. Açıköğretim Fakültesinde 2000 yılında öğretim üyesi olarak çalışmaya başlayan Erdem Aydın, 2016 yılında doçentlik unvanını kazanmıştır. Yazarın ilgilendiği konular arasında çevrimiçi öğrenme ortamlarında kültürel farklılıklar, açık ve uzaktan öğrenme ortam tasarımı, sosyal medya ve öğrenme gibi konular yer almaktadır.

Posta adresi: Anadolu Üniversitesi Açıköğretim Fakültesi, Eskişehir Tel (İş) : +90 22233505 80/5881

Eposta: ieaydin@anadolu.edu.tr

URL: https://orcid.org/0000-0003-3618-4123 